\title{
Genesis of Cryogenian Datangpo manganese deposit: Hydrothermal influence and episodic post-glacial ventilation of Nanhua Basin, South China
}

Wenchao $\mathrm{Yu}^{\mathrm{a}, \mathrm{b}, \mathrm{c}}$, Thomas J. Algeo ${ }^{\mathrm{a}, \mathrm{b}, \mathrm{c}}$, Yuansheng Du ${ }^{\mathrm{a}, \mathrm{b}^{*}}$, Barry Maynard ${ }^{\mathrm{c}}$, Hua

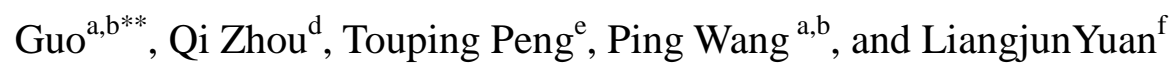

a State Key Laboratory of Biogeology and Environmental Geology, China University of Geosciences-Wuhan, Wuhan 430074, China

${ }^{\mathrm{b}}$ State Key Laboratory of Geological Processes and Mineral Resources, China University of Geosciences-Wuhan, Wuhan 430074, China

${ }^{c}$ Department of Geology, University of Cincinnati, Cincinnati OH 45221-0013, U.S.A.

${ }^{\mathrm{d}}$ Guizhou Bureau of Geology and Mineral Exploration and Development, Guiyang 550004, China e Guangzhou Institute of Geochemistry, China Academy of Science, Guangzhou 510640, China

${ }^{\mathrm{e}} 103$ Geological Party, Guizhou Bureau of Geology and Mineral Exploration and Development, Tongren 554300, China

Corresponding author: *duyuansheng126@126.com; Tel: +86 13971241916, Fax: +86 27 87481365; **guohuacug@ 163.com; Tel: +86 13476833986

\begin{abstract}
The Neoproterozoic Datangpo Formation of the Nanhua Basin in South China records interglacial sedimentation between the $\sim 720-660-M a$ Sturtian and 654-635-Ma Marinoan glaciations. The lower part ( $1^{\text {st }}$ Member) of this formation contains manganese-rich deposits that represent a mixture of two main components, Mn-carbonates and Mn-bearing aluminosilicates (clay minerals). The Mn-carbonate component is characterized by high La/Sc ratios, high initial ${ }^{87} \mathrm{Sr} /{ }^{86} \mathrm{Sr}$ ratios, and low initial $\varepsilon N d(t)$ values, and the siliciclastic component by low $\mathrm{La} / \mathrm{Sc}$ ratios, low initial ${ }^{87} \mathrm{Sr} /{ }^{86} \mathrm{Sr}$ ratios, and high initial $\varepsilon \mathrm{Nd}(\mathrm{t})$ values. The likely source of the non-radiogenic
\end{abstract}


siliciclastic material is weathering of Neoproterozoic continental flood basalts on the Yangtze Block. Discriminant plots show that the Mn-ore samples have compositions consistent with at least partial derivation from hydrothermal sources. Mn-carbonate deposition was the result of reactions between aqueous Mn and sedimentary organic matter during early diagenesis that led to elevated $\mathrm{Mn}^{2+}$ concentrations and alkalinity in sediment porewaters. Based on these observations, we propose a new metallogenic model for the Datangpo Formation manganese deposits. During the Sturtian glaciation, the anoxic Nanhua Basin accumulated abundant dissolved Mn, a substantial fraction of which was derived from hydrothermal sources. When glaciation ended and a redox-stratified water column developed in the basin with an oxic surface layer and an anoxic deep layer, the accumulated dissolved Mn precipitated as Mn-oxides on the basin floor during episodic ventilation events. After co-burial with organic-rich sediments, these Mn-oxides were reduced during organic matter oxidation, which led to the formation of secondary Mn-carbonates (rhodochrosite) through increases in sediment porewater $\mathrm{Mn}^{2+}$ and in alkalinity via microbial sulfate reduction and microbially mediated $\mathrm{Mn}$ reduction.

Keywords: $\mathrm{Sr}$ isotope; $\mathrm{Nd}$ isotope; $\mathrm{C}_{\mathrm{org}} / \mathrm{P}$; Sturtian glaciation; Marinoan glaciation; Yangtze Block

\section{Introduction}

The Cryogenian Period ( 720-635 Ma) was a critical interval of the Neoproterozoic characterized by the breakup of the supercontinent Rodinia, severe global climate changes, and massive metallogenic events. Breakup of Rodinia began around $750 \mathrm{Ma}$ (Eyles and Januszczak, 2004) with the formation of rift basins on the margins of Laurentia (Dehler et al., 2010; Thomson et al., 2015), Australia (de Vries et al., 2008; Preiss, 2000) and the Yangtze Block (Wang and Li, 2003) (Fig. 1A). Lengthening continental margins (Hoffman and Schrag, 2002) and intensified magmatic activity (Goddéris et al., 2003) enhanced subaerial silicate weathering and 
drew down atmospheric $\mathrm{CO}_{2}$ levels, triggering the global glaciation of the Cryogenian (Hoffman, 1999). Two major glaciation episodes ensued, the Sturtian at $~ 720-660 \mathrm{Ma}$ and the Marinoan at $\sim 654-635$ Ma (Shields-Zhou et al., 2012). Concurrently with these global tectonic and climatic events, metallogenesis produced large deposits of banded iron formations (BIF) and manganese ores. Manganese deposits of this age are widely distributed in Namibia, Brazil, India, and South China (Maynard, 2003, 2014; Roy, 2006). In Namibia and Brazil, manganese-bearing layers consist of Mn-oxides interbedded with BIF (Bühn et al., 1992; Cabral et al., 2011; Klein and Ladeira, 2004), whereas in India and South China, manganese is preserved as rhodochrosite $\left(\mathrm{MnCO}_{3}\right)$ and BIF is absent (Roy, 1990; Gutzmer and Beukes, 1998; Tang and Liu, 1999).

The Nanhua Basin began to form at $\sim 750 \mathrm{Ma}$, in conjunction with the breakup of Rodinia, due to intracontinental rifting between the Yangtze and Cathaysia blocks (Fig. 1B). This basin subsided intermittently from the late Tonian $(\sim 750 \mathrm{Ma})$ until the mid-Cambrian ( $\sim 500 \mathrm{Ma})$ but ultimately became inactive, thus representing a failed intracontinental rift basin (Wang and Li, 2003; Wang et al., 2011). Cryogenian-age ( 664-653 Ma) manganese deposits are found at the base of the Datangpo Formation and therefore known as "Datangpo-type". Studies of the Datangpo manganese deposit have provided information about its sedimentology (Xu et al., 1990), geochronology (Zhou et al., 2004; Zhang et al., 2008), organic geochemistry (Wang et al., 2008), C-S-Fe isotope chemistry (Tang and Liu, 1999; Liu et al., 2006; Chen et al., 2008; Zhang et al., 2015), and Fe speciation (Feng et al., 2010; Li et al., 2012). These studies have also revealed the linkage between Cryogenian seawater chemistry and manganese metallogenesis. They demonstrate the transition of the redox environment of the Nanhua Basin from an anoxic watermass during the Sturtian Glaciation to a redox-stratified watermass in the post-Sturtian interval, during which eustatic transgression and enhanced primary productivity increased the TOC content of deep-water sediments. All of these factors contributed to the formation of the Datangpo manganese deposit.

The source of Mn ore layer in the Datangpo Formation is still controversial, with two opposing models having been advanced. Based on the concentrically layered 
nodular structure and colloform texture of the ore, Xu et al. (1990) proposed that the Mn deposit was the product of hydrothermal activity. On the other hand, Liu et al. (2006) regarded REE patterns in the Mn deposit as not characteristic of hydrothermal influence, and they inferred a lateritic weathering origin instead. Tang and Liu (1999) also preferred lateritic sources of $\mathrm{Mn}$, but they emphasized biogenic processes in metallogenesis and, in particular, the role of marine algae in absorbing Mn from seawater, with subsequent organic decay in the sediment producing alkaline and reducing porewaters that may have resulted in the biologically mediated precipitation of $\mathrm{MnCO}_{3}$.

In this study, elemental and $\mathrm{Sr}-\mathrm{Nd}$ isotope data were generated for Cryogenian-age manganese deposits of the Nanhua Basin in drillcore ZK4207 from northeastern Guizhou Province, South China. These data served to more fully characterize the geochemical composition of these ore deposits with the goals of better understanding the source of $\mathrm{Mn}$ and mechanism of $\mathrm{Mn}$ accumulation. Our results demonstrate that (1) the Datangpo Mn ore layer consists primarily of two components, Mn-carbonates (rhodochrosite) and Mn-bearing aluminosilicates, (2) the Mn-carbonates were the product of hydrothermally sourced $\mathrm{Mn}$ and increased sediment porewater alkalinity as a result of intense microbial sulfate reduction during organic matter oxidation, (3) the source of siliciclastic material was weathering of Neoproterozoic continental flood basalts on the Yangtze Block, and (4) the distribution of Mn deposits in the Nanhua Basin conforms best to an "episodic ventilation" model of metallogenesis. Our study thus provides new insights regarding the source and metallogenic history of these important manganese deposits.

\section{Geological background}

During the Cryogenian, the study area in Songtao County in northeastern Guizhou Province was located on the southeastern margin of the Yangtze Block, within the Nanhua Rift Basin (Fig. 1B and Fig. S1). Cryogenian sedimentary successions in the study area record two glacial events. The older one, of probable Sturtian age, is recorded by glacial-marine diamictites and sandstone of the Tiesi'ao 
Formation with an average thickness of $10 \mathrm{~m}$. The younger one, of probable Marinoan age, is recorded by glacial-marine diamictites, siltstones, and sandstones of the Nantuo Formation with an average thickness of $\sim 100 \mathrm{~m}$ (Fig. 2).

The interglacial Datangpo Formation has conformable contacts with both the underlying Tiesi'ao and overlying Nantuo formations. Data collected from 162 drillcores shows that the thickness of the Datangpo Formation varies regionally from 30 to $700 \mathrm{~m}$ (Zhou et al., 2016). At most locales, the Datangpo Formation shows no evidence of intraformational hiatuses, suggesting a continuously deposited succession. The large changes in strata thickness were controlled by the paleobathymetry of the Nanhua Rift Basin, which comprised a series of NE-SW-trending horsts and grabens, characterized respectively by thinner and thicker deposits (Fig. 2) (BGMRGZP, 1987; Zhou et al., 2016). The Datangpo Formation is subdivided into three members, with the $1^{\text {st }}$ Member consisting of Mn-rich sediments, the $2^{\text {nd }}$ Member of pyritic black shales, and the $3^{\text {rd }}$ Member, being much thicker than the other two, of gray mudstones and siltstones. The Mn-rich $1^{\text {st }}$ Member consists of massive Mn-carbonate (rhodochrosite) interbedded with Mn-bearing shale, both having a high organic carbon content and abundant pyrite. The Mn-carbonates represent a Mn ore layer with a thickness ranging from 0.5 to $15 \mathrm{~m}$. Both the Mn-rich and black shale members are found mainly in the grabens of the Nanhua Rift Basin (Fig. 2). The Datangpo Formation exhibits moderate thermal maturity, as shown by $\mathrm{R}_{\mathrm{o}}$ values of $2.1-2.8 \%$ and pristane/phytane ratios ( $\mathrm{Pr} / \mathrm{Ph})$ of 0.9-1.2 (Wang et al., 2008).

The Datangpo Formation contains a basal tuff that has been dated by the TIMS zircon $\mathrm{U}-\mathrm{Pb}$ method to $662.9 \pm 4.3 \mathrm{Ma}$ (Zhou et al., 2004), an age that conforms to the termination of the Sturtian glaciation (Rooney et al., 2014). A second tuff near the top of the Datangpo Formation was dated by the LA-ICP-MS zircon U-Pb method to 654.5 $\pm 3.8 \mathrm{Ma}$ (Zhang et al., 2008). These radiometric dates suggest that the interglacial interval between the Sturtian and Marinoan glaciations, as recorded by the Datangpo Formation in South China, lasted for $\sim 8.4 \pm 8.1$ Myr. Combined with stratal thickness data, we estimate the average accumulation rate of the Datangpo Formation to have been between 8.8 and $88 \mathrm{~m} \mathrm{Myr}^{-1}$ with a mean estimate of $48 \mathrm{~m} \mathrm{Myr}^{-1}$. 


\section{Manganese geochemistry}

Manganese and iron have similar geochemical characteristics, both being strongly redox-dependent in aqueous systems. Under reducing conditions, manganese converts to soluble $\mathrm{Mn}(\mathrm{II})$, occurring in seawater as $\mathrm{Mn}^{2+}$ or $\mathrm{MnCl}^{+}$ions. Under oxidizing conditions, manganese converts to relatively insoluble $\mathrm{Mn}(\mathrm{III})$ or $\mathrm{Mn}(\mathrm{IV})$, forming solid-phase Mn-oxides or hydroxides (Tribovillard et al., 2006). Mn(II) oxidation is commonly facilitated by autotrophic microbial activities (Tebo et al. 2004; Morgan, 2005), as a consequence of which formation of authigenic Mn-OOH phases is often accompanied by large amounts of reactive microbial organic matter in the sediment (Polgári et al., 2012a, 2016). In aqueous systems with oxidizing waters overlying anoxic waters (as in anoxic marine basins and most marine sediments), $\mathrm{Mn}$ is vertically cycled, with solid-phase $\mathrm{Mn}(\mathrm{IV})$ particulates that form at or just above the redoxcline being reductively dissolved within the deeper water column or at/below the sediment-water interface (Calvert and Pedersen, 1996; Roy, 2006; Maynard, 2003, 2014).

The conditions of formation of manganese ore deposits are an important and controversial issue (Stille et al., 1989; Okita and Shanks Iii, 1992; Nicholson et al., 1997; El Rhazi and Hayashi, 2003; Del Rio-Salas et al., 2013). Three types of Mn-oxyhydroxide deposits have been identified in marine settings (Glasby, 2006): (1) Mn nodules in the deep ocean (generally at water depths >4000 m), (2) Mn crusts on submarine seamounts and plateaus at $<1000 \mathrm{~m}$ depth, and (3) ferromanganese concretions in shallow-marine environments. Mn nodules are hydrogenous in origin because they form directly from seawater in an oxidizing environment. The manganese in Mn crusts and concretions can be sourced either hydrogenously or hydrothermally. Hydrogenous Mn crusts are characterized by slow growth ( 1-5 mm $\mathrm{kyr}^{-1}$ ) and enrichment in $\mathrm{Co}, \mathrm{Cu}, \mathrm{Ni}$, and $\mathrm{Zn}$. Mn crusts formed in the vicinity of hydrothermal vents are characterized by higher growth rates (to $>1,000 \mathrm{~mm} \mathrm{kyr}^{-1}$ ) and lower trace element concentrations, and they can be enriched in metals such as Mo, 
Ba, and Li (Glasby, 2006; Bau et al., 2014).

Manganese carbonates commonly form in redox-stratified basins with anoxic deep waters, leading to an association with black shale (Force and Cannon, 1988; Frakes and Bolton, 1992; Calvert and Pedersen, 1996). The manganese carbonate minerals are rhodochrosite $\left(\mathrm{MnCO}_{3}\right)$ and kutnohorite $\left[\mathrm{CaMn}\left(\mathrm{CO}_{3}\right)_{2}\right]$. Mn-carbonate precipitation used to be considered the product of a simple pair of redox reactions (Huckriede and Meischner, 1996; Liu et al., 2006; Roy, 2006), but recent research has shown that the reduction of Mn-oxyhydroxides and oxidation of organic matter $\left(\mathrm{CH}_{2} \mathrm{O}\right)$ is in fact a process mediated by heterotrophic microbial activity (Morgan, 2005; Polgári et al., 2012a, b, 2013, 2016). This process leads to an increase in porewater Mn levels, causing saturation with respect to Mn-carbonate:

$$
2 \mathrm{MnO}_{2}+\mathrm{CH}_{2} \mathrm{O}+\mathrm{HCO}_{3}^{-} \leftarrow \rightarrow 2 \mathrm{MnCO}_{3}+\mathrm{H}_{2} \mathrm{O}+\mathrm{OH}^{-}
$$

This process is characteristic of areas in which suboxic waters are present at or just below the sediment-water interface, leading to utilization of Mn-oxyhydroxides as an oxidant. Such conditions can be found at the redoxcline in stably stratified anoxic marine basins such as the modern Black Sea. In this case, Mn carbonates form in a ring on the slopes of the basin where the redoxcline intersects the seafloor, representing the "bathtub ring model" (Fig. 3A) (Force and Cannon, 1988; Frakes and Bolton, 1992). Alternatively, some anoxic marine basins are subject to frequent oxygenation of the deep basin floor through hyperpycnal flows, resulting in transiently oxic to suboxic conditions as deepwater oxidants are consumed. In the modern Baltic Sea, the anoxic deep Gotland Basin has been repeatedly ventilated in this manner at intervals of a few years throughout the past century. This process leads to precipitation of $\mathrm{Mn}$ oxides in a basin-center pattern and conversion to $\mathrm{Mn}$ carbonates during early diagenesis, resulting in a close association with deepwater black shales. Huckriede and Meischner (1996) described the basic features of this model but did not name it; herein, we name it the "episodic ventilation" model (Fig. 3B). 


\section{Materials and methods}

The drillsite ZK4207 is located $3 \mathrm{~km}$ southwest of Taiping Village, Songtao County, in northeastern Guizhou Province; its GPS coordinates are $28^{\circ} 2^{\prime} 24^{\prime \prime} \mathrm{N}$, $109^{\circ} 5^{\prime} 2^{\prime \prime} \mathrm{E}$ (Fig. S1). The total thickness of the Datangpo Formation in this drillcore is $370 \mathrm{~m}$, comprising $13 \mathrm{~m}$ of Mn-rich strata $\left(1^{\text {st }}\right.$ Member $), 27 \mathrm{~m}$ of black shale $\left(2^{\text {nd }}\right.$ Member), and $330 \mathrm{~m}$ of siltstone $\left(3^{\text {rd }}\right.$ Member). The $1^{\text {st }}$ Member consists of four horizontally laminated Mn-shale layers with three interbedded Mn-carbonate layers. The Mn-shale layers are thinner (from 0.29 to $1.27 \mathrm{~m}$ ) than the Mn-carbonate layers (from 0.51 to $7.41 \mathrm{~m}$; Fig. 4). A total of forty samples were collected from this drillcore including one sample of carbonaceous shale from the top of the Tiesi'ao Formation (ZK 4207-77); one sample of Mn-shale from the Tiesi'ao-Datangpo formation contact (ZK 4207-0); 29 samples of Mn-carbonate and Mn-shale from the $1^{\text {st }}$ Member of the Datangpo Formation (ZK 4207-1 to -29); six samples of black shale from the $2^{\text {nd }}$ Member ( $\mathrm{ZK} 4207-30$ to -35 ); one sample of siltstone from the $3^{\text {rd }}$ Member (ZK 4207-36); and two samples of diamictite from the overlying Nantuo Formation (ZK4207-37 and -38) (Fig. 4).

Scanning electron microscopy (SEM) using the energy dispersive spectroscopic (EDS) mode was carried out on a FEI Quanta 450 FEG-SEM in the State Key Laboratory of Geological Processes and Mineral Resources (GPMR), China University of Geosciences (Wuhan).

To investigate the mineralogical composition of samples, X-ray diffraction (XRD) studies were performed with a PANalytical X'Pert Pro instrument in the State Key Laboratory of Geological Processes and Mineral Resources (GPMR), China University of Geosciences (Wuhan). Operating conditions included continuous scanning using a $\mathrm{Cu}-\mathrm{Ni}$ tube at $40 \mathrm{kV}$ and $40 \mathrm{~mA}$ at a speed of $8 \% \mathrm{~min}$. The mass percentages (mass\%) of the main mineral phases were determined semi-quantitatively with an analytical error of $\pm 3 \%$.

Elemental analysis was carried out by the ALS Chemex Laboratory (Guangzhou, China). Major elements were determined using a Rigaku 3080E X-ray fluorescence 
spectrometer $(\mathrm{XRF})$, with analytical uncertainties of $<3 \%$. A pre-ignition method was used to determine the loss on ignition (LOI) prior to major element analysis. Trace elements and rare earth elements (REEs) were determined using a PerkinElmer Elan 9000 type ICP-MS, for which sample preparation entailed dissolution of $\sim 40 \mathrm{mg}$ of powder in a $\mathrm{HF}+\mathrm{HNO}_{3}$ mixture in a high-pressure Teflon bomb. An internal standard solution containing the single element $\mathrm{Rh}$ was used to monitor signal drift, and analytical precision was generally better than $\pm 5 \%$. Reported REE concentrations were normalized ('N') to upper continental crust (UCC) (Rudnick and Gao, 2003).

Total organic carbon (TOC) was determined using an Analytik Jena Multi EA 4000 type C-S analyzer at the State Key Laboratory of Biogeology and Environmental Geology (BGEG), China University of Geosciences (Wuhan). Analytical precision is $\pm 0.2 \%$.

$\mathrm{Sr}$ and $\mathrm{Nd}$ isotopic ratios were measured by a VG 354 isotope ratio mass spectrometer at the Guangzhou Institute of Geochemistry, Chinese Academy of Sciences (CAS). Samples were heated to $150{ }^{\circ} \mathrm{C}$ to eliminate organic matter. The analytical procedure followed that of $\mathrm{Li}$ et al. (2004). The mass fractionation corrections for $\mathrm{Sr}$ and $\mathrm{Nd}$ isotopic ratios were normalized to ${ }^{86} \mathrm{Sr} /{ }^{88} \mathrm{Sr}=0.1194$ and ${ }^{146} \mathrm{Nd} /{ }^{144} \mathrm{Nd}=0.7219$, respectively. The La Jolla standard gave ${ }^{143} \mathrm{Nd} /{ }^{144} \mathrm{Nd}=$ $0.511862\left( \pm 10 \times 10^{-6}\right)(\mathrm{n}=6)$, and the NIST SRM 987 standard gave ${ }^{87} \mathrm{Sr} /{ }^{86} \mathrm{Sr}=$ $0.710265\left( \pm 12 \times 10^{-6}\right)(\mathrm{n}=6)$. Analytical blanks were in the range of 200-500 pg for $\mathrm{Sr}$ and $<50 \mathrm{pg}$ for $\mathrm{Nd}$. The ${ }^{87} \mathrm{Rb} /{ }^{86} \mathrm{Sr}$ and ${ }^{147} \mathrm{Sm} /{ }^{144} \mathrm{Nd}$ ratios were calculated using the $\mathrm{Rb}$, $\mathrm{Sr}, \mathrm{Sm}$, and Nd contents measured by ICP-MS.

\section{Results}

\subsection{Petrographic and mineralogic observations}

The manganese ore in the $1^{\text {st }}$ Member of the Datangpo Formation is associated with microcrystalline quartz veins of probable early diagenetic origin. Rhodochrosite $\left(\mathrm{MnCO}_{3}\right)$ is the dominant mineral $(20-30 \%)$ in the Mn-ore samples. The diameters of 
spherical rhodochrosite crystals vary from 2 to $10 \mu \mathrm{m}$ (Fig. 5A-B). Microlayers of pyrite, clay minerals (mostly illite), and rhodochrosite are observed in the Mn ore samples (Fig. 5C). Some terrigenous detrital minerals such as quartz, feldspar, and clay minerals of silt or finer size were also observed (Fig. 5D). The proportion of detrital minerals increases in the Mn-shale samples with lower rhodochrosite content. Pyrite is abundant in the Mn-shale and black shale samples, either as framboids or disseminated euhedral grains (Fig. 5C-D). EDS analysis indicates that $\mathrm{Ca}$ and $\mathrm{Mg}$ are also present in the rhodochrosite crystals (Fig. 5E-F). Organic matter-filled microfractures are common. The organic matter in the Mn ore samples is black or dark brown, amorphous, and typically found around the margins of the rhodochrosite crystals.

XRD results show that all Mn-ore and Mn-shale samples from the $1^{\text {st }}$ Member of the Datangpo Formation have high quartz (22-40 \% with a mean of $33 \%)$ and illite (14-43\% with a mean of $30 \%$ ) contents (Table 1). Feldspar is common in all samples, ranging from $2 \%$ to $16 \%$, being higher in the Mn-shale samples (mean $10 \%$ ) than the Mn-ore samples (mean $5 \%$ ). The main carbonate minerals are rhodochrosite and dolomite. In the Mn-ore samples, rhodochrosite content ranges from $11 \%$ to $35 \%$ (mean $16 \%$ ) and dolomite content ranges from $8 \%$ to $28 \%$ (mean $14 \%$ ). Carbonate content is lower in the Mn-shale samples, with 1-10\% rhodochrosite (mean $5 \%$ ) and 4-22 \% dolomite (mean $8 \%$ ). Pyrite is the main Fe-bearing mineral with an average content of $3 \%$.

\subsection{Major elements}

The base of the Datangpo Formation is marked by a large increase in Mn content (from $<0.1 \%$ to $2.5 \%$ ). Twenty-one Mn-ore samples from the $1^{\text {st }}$ Member are characterized by high $\mathrm{Mn}(11.6-29.8 \%$ with a mean of $19.8 \%)$, low $\mathrm{Fe}_{2} \mathrm{O}_{3}(2.8-5.2 \%$ with a mean of $4.1 \%)$, low $\mathrm{Al}_{2} \mathrm{O}_{3}(3.6-12.6 \%$ with a mean of $8.4 \%)$, intermediate $\mathrm{SiO}_{2}(20.1-40.5 \%$ with a mean of $35.1 \%)$, and $\mathrm{Mn} / \mathrm{Fe}$ ratios in the range of 2.3-8.9. In eight Mn-bearing shale samples from the $1^{\text {st }}$ Member, Mn content is lower 
(2.5-10.3\% with a mean of 7.8\%), $\mathrm{Al}_{2} \mathrm{O}_{3}$ is higher (9.3-14.6\% with a mean of $12.3 \%), \mathrm{SiO}_{2}$ is higher (42.4-61.1\% with a mean of 50.8\%), and $\mathrm{Mn} / \mathrm{Fe}$ ratios are lower (0.8-4.1) than in the Mn-ore samples (Table 2).

Samples from the Tiesi'ao Formation shale have a high TOC content (2-3\%). The TOC content of the Mn-rich $1^{\text {st }}$ Member of the Datangpo Formation is 1.4-3.5\% with a mean of $2.1 \%$. The TOC content increases to $2.4-3.5 \%$ with a mean of $2.9 \%$ in black shales of the $2^{\text {nd }}$ Member, and then it decreases to $\sim 0.2 \%$ in siltstones of the $3^{\text {rd }}$ Member. Two diamictite samples from the overlying Nantuo Formation contain 0.3-0.8\% TOC (Fig. 4B).

Molar $\mathrm{C}_{\text {org }} / \mathrm{P}$ ratios can be utilized to distinguish benthic redox conditions in sedimentary rocks (Algeo and Ingall, 2007). In the study units, molar $\mathrm{C}_{\mathrm{org}} / \mathrm{P}$ ratios are strongly lithology-dependent. The Mn-rich $1^{\text {st }}$ Member of the Datangpo Formation yields ratios of 10-56, indicating an oxic environment. Black shales of the Tiesi'ao Formation and the $2^{\text {nd }}$ Member of the Datangpo Formation are higher, ranging from 50 to 228 , indicating a suboxic to anoxic environment. Siltstones of the $3^{\text {rd }}$ Member of the Datangpo Formation and the Nantuo Formation yield lower ratios, 14 and 22-52, respectively, indicating oxic environments (Fig. 4B).

Crossplots of elements associated with the two main mineral fractions of the study samples (i.e., clay minerals and Mn-carbonates) show strong negative covariation, e.g., $\mathrm{Al}_{2} \mathrm{O}_{3}$-vs-Mn $(r=-0.91 ; p(\alpha)<0.01)$ and $\mathrm{SiO}_{2}$-vs-Mn $(r=-0.97$; $p(\alpha)<0.01$ ) (Fig. 6A, Fig. S2; note that $p(\alpha)<0.05$ and $<0.01$ indicate significance at $2 \sigma$ and $3 \sigma$ levels, respectively). Patterns of negative covariation are forced in sediments consisting dominantly of two components, as here. The purpose of these crossplots is not merely to demonstrate such negative covariation but, rather, to identify which samples most closely represent the two compositional endmembers of the sediment, in order to subsequently define the isotopic characteristics of these endmembers. Moderate positive correlations are shown by $\mathrm{CaO}-\mathrm{vs}-\mathrm{Mn}(r=+0.73$; $p(\alpha)<0.05)$ and $\mathrm{MgO}$-vs-Mn $(r=+0.66 ; p(\alpha)<0.05)$ because these elements are present mainly in the Mn-carbonate fraction (Fig. 6B, Fig. S2). The $y$-intercepts in these crossplots represent the average concentrations of $\mathrm{CaO}$ and $\mathrm{MgO}$ in the detrital 
fraction of the samples.

Iron $(\mathrm{Fe})$ in the study samples is associated mainly with pyrite $\left(\mathrm{FeS}_{2}\right)$ and secondarily with Fe-bearing clay minerals. Fe-vs-S exhibits a significant positive correlation $(r=+0.89 ; p(\alpha)<0.01)$ (Fig. S2) in the Mn-ore and Mn-bearing shale samples, indicating $\mathrm{Fe}$ is present mainly in pyrite in the $1^{\text {st }}$ Member of the Datangpo Formation.

\subsection{Trace and rare earth elements}

The ranges for concentrations of $\mathrm{Rb}, \mathrm{Sr}, \mathrm{Sm}$, and $\mathrm{Nd}$ in the study samples are 31-118 ppm, 99-297 ppm, 6-14 ppm, and 30-60 ppm, respectively. Some metals (e.g., $\mathrm{Co}, \mathrm{Cr}, \mathrm{Ni}, \mathrm{Cu}, \mathrm{Zn}$ ) have much lower concentrations in Mn-ore and Mn-shale samples of the $1^{\text {st }}$ Member of the Datangpo Formation than typical $\mathrm{Mn}-\mathrm{Fe}$ nodules in the modern ocean (Nicholson, 1992; Hein et al., 1994) (Table 3). The $\Sigma$ REE abundances of samples range from 143 to $325 \mathrm{ppm}$, with a mean of $238 \mathrm{ppm}$ (Table 4). Mn-ore and Mn-shale samples from the $1^{\text {st }}$ Member show LREE-depleted and HREE-enriched patterns $\left(\mathrm{La}_{\mathrm{N}} / \mathrm{Yb}_{\mathrm{N}}=0.61-0.81\right.$ with a mean of 0.69$)($ Fig. $7 \mathrm{~A}) . \mathrm{La} / \mathrm{Sc}$ ratios in the Mn-ore samples (mean 6.7) are higher than those in Mn-shale samples (mean 4.7). Positive $\mathrm{Ce}$ anomalies are common in the Mn-ore and Mn-shale samples. Both positive and negative $\mathrm{Eu} / \mathrm{Eu}^{*}$ are seen in the $\mathrm{Mn}$-ore and $\mathrm{Mn}$-shale samples, and there is a positive correlation between Eu anomalies and $\mathrm{Mn}$ content. Black shale and siltstone samples from the $2^{\text {nd }}$ and $3^{\text {rd }}$ members of the Datangpo Formation and samples from the Tiesi'ao and Nantuo formations have rather flatter REE patterns, indicating that the compositions of these samples are closer to that of the upper continental crust. Negative Eu anomalies are obvious in samples from the Tiesi'ao and Nantuo formations (Fig. 7B-C).

\subsection{Sr and Nd isotopes}

The $\mathrm{Sr}$ and $\mathrm{Nd}$ isotope results and calculated $\mathrm{Nd}$-depleted mantle model ages 
$\left(\mathrm{T}_{\mathrm{DM}}\right)$ and two-stage $\mathrm{Nd}$ model ages $\left(\mathrm{T}_{2 \mathrm{DM}}\right)$ for Mn-ore and $\mathrm{Mn}$-shale samples from the $1^{\text {st }}$ Member of the Datangpo Formation are shown in Table 5. Initial ${ }^{87} \mathrm{Sr} /{ }^{86} \mathrm{Sr}$ $\left({ }^{87} \mathrm{Sr} /{ }^{86} \mathrm{Sr}\right)$ ratios range from 0.707585 to $0.719335 .{ }^{147} \mathrm{Sm} /{ }^{144} \mathrm{Nd}$ ratios fall in the range of $0.10-0.15$ with a mean of 0.13 . Initial $\varepsilon N d(t)$ values are in the range of -5.3 to -1.6 . Samples with ${ }^{147} \mathrm{Sm} /{ }^{144} \mathrm{Nd}$ ratios either $>0.13$ or $<0.10$ are used for $\mathrm{T}_{2 \mathrm{DM}}$ instead of $\mathrm{T}_{\mathrm{DM}}$ to minimize the bias caused by $\mathrm{Sm}-\mathrm{Nd}$ fractionation ( $\mathrm{Li}$ and McCulloch, 1996; Wang et al., 2011). $\mathrm{T}_{\mathrm{DM}}$ ranges from $1.46 \mathrm{Ga}$ to $1.79 \mathrm{Ga}$, with most values between $1.50 \mathrm{Ga}$ and $1.70 \mathrm{Ga}$. A positive correlation between Mn content and $\mathrm{i}^{87} \mathrm{Sr} /{ }^{86} \mathrm{Sr}(r=+0.69 ; p(\alpha)<0.01)$ and a negative correlation between $\mathrm{Al}_{2} \mathrm{O}_{3}$ content and $\mathrm{i}^{87} \mathrm{Sr} /{ }^{86} \mathrm{Sr}(r=-0.78 ; p(\alpha)<0.01)$ are observed (Fig. 6C-D). Similarly, a positive correlation between $\mathrm{Mn}$ content and initial $\varepsilon \mathrm{Nd}(\mathrm{t})(r=+0.64 ; p(\alpha)<0.01)$ and a negative correlation between $\mathrm{Al}_{2} \mathrm{O}_{3}$ content and initial $\varepsilon \mathrm{Nd}(\mathrm{t})(r=-0.73 ; p(\alpha)<0.01)$ are observed (Fig. 6E-F). A negative correlation is evident in a crossplot of $i^{87} \mathrm{Sr} /{ }^{86} \mathrm{Sr}$ versus initial $\varepsilon N d(t)(r=-0.58 ; p(\alpha)<0.05)$ (Fig. 8). These observations show that distinctly different $\mathrm{Sr}$ and $\mathrm{Nd}$ isotopic compositions are associated with the two endmember components of the $1^{\text {st }}$ Member of the Datangpo Formation.

\section{Discussion}

\subsection{Manganese-rich sediments in modern redox-stratified basins}

Manganiferous nodules, crusts, and concretions composed of Mn-oxyhydroxides accumulate in many modern marine settings, including the central Pacific Ocean, the Red Sea, and the Black Sea. These precipitates consist mainly of $\mathrm{MnO}_{2}$ and amorphous $\mathrm{FeOOH}$, usually show a layered growth structure, and have Mn content of 5-33 \% (Maynard, 2003, 2014). Apart from deep-ocean Mn-nodules whose accumulation depends on exceedingly slow sedimentation rates, the formation of Mn-oxyhydroxides in restricted marine basins is generally linked to water-column redoxclines (Glasby, 2006). On the other hand, the accumulation of Mn-carbonates in 
the modern ocean is relatively limited, with occurrences in the deeper parts of restricted basins such as the Baltic Sea, Loch Fyne in Scotland, and the Panama Basin. This contrasts with the pattern in ancient rocks, in which Mn-carbonates are preponderant among manganiferous ores and proto-ores (Maynard, 2003, 2014).

The Black Sea, which is strongly redox stratified, is known to accumulate only Mn-oxides in sediments close to the redoxcline, thus in a bathtub ring pattern around the margin of its basin (Force and Cannon, 1988). Fe-Mn-hydroxide concretions are present at and below the sediment-water interface in three layers to a depth of $1.5 \mathrm{~m}$ with 6-14 \% Mn content (Baturin, 1987; Murray and Tebo, 1991). The absence of $\mathrm{Mn}$-carbonates has been attributed to low $\mathrm{Mn}^{2+}$ concentrations in sediment porewaters. Beneath the redoxcline, Mn concentrations decrease with depth in porewaters and reach stable levels at $\sim 1-2 \mathrm{~cm}$ below the sediment-water interface, suggesting the depletion of reactive Mn around this depth (Sternbeck and Sohlenius, 1997; Thamdrup et al., 2000). The low $\mathrm{Mn}^{2+}$ concentration of porewaters is due to low organic carbon fluxes to the sediment, thus creating low reducing potential. Low organic carbon fluxes also result in low sulfate reduction rates, which reduces the potential for secondary carbonate formation because microbial sulfate reduction (MSR) is a common source of increased porewater alkalinity (Thamdrup et al., 2000).

In the Baltic Sea, Mn-rich sediments average $\sim 2 \mathrm{~m}$ in thickness and contain 2-5\% manganese (Huckriede and Meischner, 1996). They are mainly restricted to the deep, stratified Gotland, Faro, and Landsort basins, which accumulate a complex diagenetic assemblage of Mn-carbonates (both rhodochrosite and kutnohorite) and Mn-sulfides (Neumann et al., 2002). Their formation is linked with episodic inflows of oxic North Atlantic surface waters that spill over the Danish Straits under specific meteorological conditions (Sternbeck and Sohlenius, 1997). These high-salinity surface waters sink rapidly to the bottom of the brackish Baltic Sea water column, ventilating the deep basins usually for periods of a few months to a few years until the dissolved oxygen is consumed through redox reactions (Neumann et al., 1997). These episodes cause rapid oxidation of dissolved $\mathrm{Mn}$ ions to insoluble $\mathrm{Mn}(\mathrm{IV})$, accumulation of particulate Mn-oxides at the sediment-water interface, and 
subsequent microbially mediated reductive dissolution of these particulates after bottom-water oxygen has been consumed (Huckriede and Meischner, 1996; Polgári et al., 2012a). This process produces high benthic $\mathrm{Mn}^{2+}$ concentrations that, in combination with high carbonate alkalinity related to MSR, can lead to the formation of Mn-carbonate precipitates (Burke and Kemp, 2002). The light C-isotopic composition of the Mn-carbonate $\left(\delta^{13} \mathrm{C}\right.$ of -14 to $-6 \%$ ) indicates that alkalinity is due mainly to remineralization of organic matter (Huckriede and Meischner, 1996; Lepland and Stevens, 1998).

Mn-carbonates are found replacing Mn-oxides in Loch Fyne, Scotland (Calvert and Price, 1970) and the Panama Basin (Pedersen and Price, 1982). Loch Fyne sediments are silty muds containing nodular masses of Mn-oxides that are commonly cemented and replaced by Mn-carbonates. The reduction of Mn-oxides occurs at a shallow depth $(\sim 10 \mathrm{~cm})$ beneath the sediment-water interface, resulting in strongly elevated porewater $\mathrm{Mn}^{2+}$ concentrations (Bartlett et al., 2007). The light $\mathrm{C}$-isotopic signature of the Mn-carbonates $\left(\delta^{13} \mathrm{C}\right.$ of $-6.0 \%$ ) indicates a carbon source from organic matter, related to MSR and a consequent increase in porewater alkalinity (Pedersen and Price, 1982). The replacement of Mn-oxides by Mn-carbonates in the coarse volcaniclastic debris of the Panama Basin has a different origin. There, Mn-carbonates have heavier $\mathrm{C}$-isotopic signatures $\left(\delta^{13} \mathrm{C}\right.$ of $\left.-2.6 \%\right)$, indicating that the carbon is of inorganic (i.e., seawater bicarbonate) rather than organic origin (Pedersen and Price, 1982).

The modern marine system that may represent the closest analog to the Neoproterozoic Nanhua Basin is the Red Sea. Multiple rift zones on the Rea Sea seafloor are characterized by strong hydrothermal activity (Cocherie et al., 1994), and numerous subbasins have developed a stratified water column in which an anoxic, metal-rich, high-temperature brine layer is found beneath an oxic normal-salinity surface layer (Schmidt et al., 2003; Butuzova et al., 2009). In these subbasins, the surface and deep layers are commonly separated by an intermediate layer exhibiting sharp redox and salinity gradients and marked by Fe-Mn-oxyhydroxide accumulation (Butuzova et al., 2009). From the surface layer to the basinal brine layer, ${ }^{87} \mathrm{Sr} /{ }^{86} \mathrm{Sr}$ 
ratios decrease from 0.70917 (typical of modern seawater) to 0.70711 owing to hydrothermal extraction of non-radiogenic Sr from underlying basaltic oceanic crust. Hydrogenous (i.e., seawater-derived) and hydrothermal sediments in the Red Sea have distinctly different $\mathrm{Sr}$ and $\mathrm{Nd}$ isotopic compositions, with hydrogenous sediments having higher ${ }^{87} \mathrm{Sr} /{ }^{86} \mathrm{Sr}$ ratios $(0.708576$ versus 0.707547$)$ and lower $\varepsilon N d(t)$ values (-3.1 versus -0.9) than hydrothermal sediments (Fig. 9) (Cocherie et al., 1994; Anschutz et al., 1995).

The observation that distinct hydrogenous and hydrothermal sources can be distinguished in spatially proximal settings of the modern Red Sea suggests that such distinctions may be possible in paleo-marine systems as well. $\mathrm{Sr}$ and $\mathrm{Nd}$ isotopes have been utilized for this purpose in several studies of Mesozoic Mn deposits (Fig. 9). The Jurassic Molango deposit in Mexico and the Pennine Alpine deposit in Italy are both mainly composed of Mn-oxides (Stille et al., 1989; Doe et al., 1996). The Sr and Nd isotope values in these $\mathrm{Mn}$ deposits are equal to or a little higher than those of contemporaneous seawater, so these Mn deposits are inferred to record paleoseawater $\mathrm{Sr}$ and $\mathrm{Nd}$ compositions and, thus, to have a dominantly hydrogenous origin.

\subsection{Origin of manganese deposits in Datangpo Formation}

Geochemical patterns show that the Mn-rich sediments of the $1^{\text {st }}$ Member of the Datangpo Formation consist largely of a mixture of two components: Mn-carbonates and aluminosilicates (clay minerals) (see Section 5.4). These samples exhibit a wide range of $i^{87} \mathrm{Sr} /{ }^{86} \mathrm{Sr}$ ratios $(0.707585-0.719335)$ that are mostly higher than the ${ }^{87} \mathrm{Sr} /{ }^{86} \mathrm{Sr}$ ratio of Neoproterozoic seawater ( 0.7075) (Halverson et al., 2007). Similarly, the range of initial $\mathrm{Nd}(\mathrm{t})$ values $(-5.3$ to -1.6$)$ in these samples is broader and mostly higher than that of Cryogenian seawater from the Yangtze Block (about - 4) (Yang et al., 1997). A negative correlation for $\mathrm{Al}_{2} \mathrm{O}_{3}-\mathrm{vs}-\mathrm{i}^{87} \mathrm{Sr} /{ }^{86} \mathrm{Sr}(r=-0.78$; Fig. 6D) and a positive correlation for $\mathrm{Al}_{2} \mathrm{O}_{3}-\mathrm{vs}-\varepsilon \mathrm{Nd}(\mathrm{t})(r=+0.73$; Fig. $6 \mathrm{~F})$ indicate that the aluminosilicate clastic component of the Mn-rich $1^{\text {st }}$ Member is characterized by low initial ${ }^{87} \mathrm{Sr} /{ }^{86} \mathrm{Sr}$ ratios and high initial $\varepsilon \mathrm{Nd}(\mathrm{t})$ values. In contrast, a positive correlation 
for $\mathrm{Mn}-\mathrm{vs}-\mathrm{i}^{87} \mathrm{Sr} /{ }^{86} \mathrm{Sr}(r=+0.69$; Fig. $6 \mathrm{C})$ and a negative correlation for Mn-vs- $\varepsilon \mathrm{Nd}(\mathrm{t})$ $(r=-0.64$; Fig. 6E) indicate that the Mn-carbonate component of these samples is linked with high $\mathrm{i}^{87} \mathrm{Sr} /{ }^{86} \mathrm{Sr}$ ratios and low $\varepsilon \mathrm{Nd}(\mathrm{t})$ values.

Changes in $\varepsilon \mathrm{Nd}(\mathrm{t})$ values during the Neoproterozoic were related to the breakup of Rodinia. An unusual decrease in $\mathrm{Nd}$ model ages and a prominent positive $\mathrm{Nd}$ isotopic shift have been observed in Yangtze Block successions of mid to late Neoproterozoic age (Li and McCulloch, 1996; Chen and Jahn, 1998; Wang et al., 2011; Fig. 10A-C). This was accompanied by an increase in Neoproterozoic seawater $\varepsilon N d(t)$ values (Yang et al., 1997). A significant positive shift in $\varepsilon N d(t)$ values (from -12 to -4 ) has also been reported from pre-Sturtian sedimentary rocks of the Adelaide Rift Complex and the Amadeus and Officer basins in south-central Australia (Barovich and Foden, 2000) (Fig. 10B). All of these Nd isotopic shifts have been interpreted as evidence of inputs of juvenile crustal materials. In South China, there are two continental growth events (at $\sim 825 \mathrm{Ma}$ and $\sim 750 \mathrm{Ma}$ ) that are linked to the breakup of Rodinia, rift magmatism, and orogen collapse (Zheng et al., 2007). Continental flood basalts with ages of $\sim 825-750 \mathrm{Ma}$ are thought to have been the source for high- $\varepsilon N d(t)$ siliciclastics (Li and McCulloch, 1996; Wang et al., 2011). Neoproterozoic sedimentary rocks in South China exhibit a pronounced mixing trend between mafic and granitic endmembers, as shown by an $\varepsilon \mathrm{Nd}(\mathrm{t})-\mathrm{vs}-\mathrm{Sc} / \mathrm{La}$ discriminant plot (Wang et al., 2011). Samples from the $1^{\text {st }}$ Member of the Datangpo Formation fall along this mixing trend, with the Mn-shales affiliated with the mafic endmember (Fig. 10D).

Several observations are inconsistent with a weathering origin for $\mathrm{Mn}$ in the $1^{\text {st }}$ Member of the Datangpo Formation. Mn exhibits a pronounced negative correlation with $\mathrm{Al}_{2} \mathrm{O}_{3}$ (Fig. 6A). Whereas the $\mathrm{Al} / \mathrm{Mn}$ ratio of upper continental crust reaches 105 (Rudnick and Gao, 2003), and Al/Mn ratios in Neoproterozoic mafic rocks of South China range from 31 to 187 with a mean of 62 (Li et al., 2002; Ling et al., 2003; Zhou et al., 2009), the $1^{\text {st }}$ Member of the Datangpo Formation yields $\mathrm{Al} / \mathrm{Mn}$ ratios from 0.09 to 4.19 with a mean of 0.68 . Such disproportionately large amounts of $\mathrm{Mn}$ are unlikely to have entered the Nanhua Basin through continental weathering because (1) 
only an extreme chemical weathering environment could yield the observed $\sim 90-150 \times$ enrichment of Mn relative to $\mathrm{Al}$ (Weber, 1997), and (2) the average chemical index of alteration (CIA; Nesbitt and Young, 1982) in South China Neoproterozoic interglacial sediments is 71 , which is indicative of low to moderate chemical weathering intensity (Dobrzinski et al., 2004).

The main source of $\mathrm{Mn}$ in the $1^{\text {st }}$ Member of the Datangpo Formation is likely to have been hydrothermal, and the Datangpo Mn deposit is a mixture of hydrothermal and hydrogenous (seawater-derived) endmember materials. Positive Eu anomalies are generally considered a useful indicator of hydrothermal activity because they are commonly associated with high-temperature fluid-rock reactions in reducing environments (Peter and Goodfellow, 1996). Some Mn-ore samples in the Datangpo Formation exhibit positive $\mathrm{Eu}$ anomalies, and a modest positive correlation exists between $\mathrm{Eu} / \mathrm{Eu}^{*}$ and $\mathrm{Mn}(r=+0.52, p(\alpha)<0.05$; Fig. 11A). Several types of discriminant plots have been proposed to distinguish hydrothermal versus hydrogenous sources of marine metalliferous sediments, e.g., $\mathrm{Y} / \mathrm{P}_{2} \mathrm{O}_{5}$-vs- $\mathrm{Zr} / \mathrm{Cr}$,

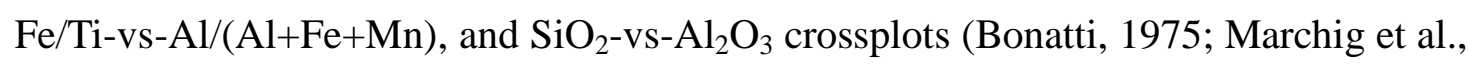
1982; Boström, 1983; Peter and Goodfellow, 1996). In these discriminant plots, Mn-ore samples from the $1^{\text {st }}$ Member of the Datangpo Formation fall closer to the hydrothermal endmember, Mn-shale samples are intermediate, and black shale and siltstone samples of the $2^{\text {nd }}$ and $3^{\text {rd }}$ members fall closer to the hydrogenous endmember (Fig. 11B-D). The hydrothermally sourced fraction is $\sim 40-60 \%$ in the Mn-ore samples, $\sim 20-40 \%$ in the Mn-shale samples, and <20\% in other samples (Fig. 11C). The importance of hydrothermal inputs is confirmed by $\mathrm{Eu} / \mathrm{Eu}^{*}$ ratios, which average 1.22 for the Mn-ore samples versus $\sim 1.5$ for the hydrothermal endmember and $\sim 0.8$ for the hydrogenous endmember (Fig. 11A). Similar geochemical patterns were reported for the Huanan Xiangtan and Tangganshan Mn deposits, which are age-equivalents of the present study units (Liu et al., 2006). As a failed rift basin, no oceanic crust formed within the Nanhua Basin, and the hydrothermal system that influenced the Datangpo Formation is likely to have developed within continental crust. This consideration accounts for the association of hydrothermally influenced 
deposits (i.e., the Mn-ore of the $1^{\text {st }}$ Member) with radiogenic $\mathrm{Sr}$ and $\mathrm{Nd}$ (Fig. 8). The Sturtian or post-Sturtian Mn deposits in Namibia, Brazil, and India have all been linked to hydrothermal sources (Roy et al., 1990; Bühn et al., 1992; Klein and Ladeira, 2004; Cabral et al., 2011). This pattern may indicate that global-ocean seawater was ferrous and manganiferous (i.e., Fe(II)- and Mn(II)-rich) during the Sturtian glacial period, and that the ultimate source of these metals was deep-ocean hydrothermal vent systems. During the post-Sturtian eustatic transgression, the Nanhua Basin reconnected with the global ocean, and manganiferous seawater flooded into the basin and formed the manganese deposits of the $1^{\text {st }}$ Member of the Datangpo Formation.

\subsection{Metallogenic model for Datangpo-type manganese deposits}

The bathtub ring model of Mn metallogenesis (Fig. 3A) is applicable to the late Neoproterozoic Urucum Mn deposit in Brazil and the Otjosondu Mn deposit in Namibia (Roy, 2006). Mn layers in these two deposits are interbedded with BIF and set in a thick sequence of diamictites containing dropstones. Both the $\mathrm{Mn}$ and $\mathrm{Fe}$ minerals in the Urucum and Otjosndu deposits are oxides (Bühn et al., 1992; Klein and Ladeira, 2004). The Mn and Fe in these deposits were sourced from deep-ocean hydrothermal vents or volcanic systems, remained dissolved in seawater during the Sturtian glacial period, and precipitated as solid-phase Mn and Fe oxides along the redoxcline in the basin margin environment following the sea level changes during the end of glaciation (Bühn et al., 1992; Klein and Ladeira, 2004; Cabral et al., 2011).

The Datangpo Formation Mn deposits do not conform to the bathtub ring model (Fig. 3A) because they are found principally in the deep subbasins of the Nanhua Basin rather than around the subbasin margins (Fig. 2). This distribution led $\mathrm{Xu}$ et al. (1990) to infer a Mn source in hydrothermal vents located in the deep subbasins of the Nanhua Basin, but large quantities of dissolved $\mathrm{Mn}^{2+}$ cannot precipitate under continuously anoxic conditions. We infer that this distribution pattern conforms best to the episodic ventilation model, in which oxygenated surface waters episodically sank into the deep anoxic subbasins (Fig. 3B). The molar $\mathrm{C}_{\text {org }} / \mathrm{P}$ ratios in the $1^{\text {st }}$ 
Member of the Datangpo Formation (10-50) indicate that both the Mn-ore and Mn-shale formed under mainly oxic conditions (Fig. 4B). Even when $\mathrm{C}_{\text {org }} / \mathrm{P}$ ratios are corrected for organic carbon lost during Mn reduction (i.e., 0.5 mole organic carbon per mole Mn, Eq. 1), the redox implications of the resulting values (16-95) remain largely unchanged. The association of Mn-carbonates of the $1^{\text {st }}$ Member with oxic depositional conditions suggests that the manganese must have been delivered to the sediment as Mn oxides or hydroxides, and that co-burial with organic-rich sediments led to subsequent $\mathrm{Mn}$ reduction in the diagenetic environment. Oxic bottomwater conditions in the central area of the Nanhua Basin are likely to have been a transient phenomenon produced by episodic density flows that carried oxygenated surface waters into the deep basin, as in the modern Baltic Sea (Neumann et al., 1997). This mechanism can also explain the interbedding of Mn-carbonates with Mn-bearing shale in the $1^{\text {st }}$ Member of the Datangpo Formation. The reaction of Mn oxides and organic matter led to the production of $\mathrm{MnCO}_{3}$ during early diagenesis (Eq. 1; Huckriede and Meischner, 1996; Liu et al., 2006; Roy, 2006). The ${ }^{13}$ C-depleted composition (-13 to $-5 \%$ ) of Datangpo Formation Mn-carbonates reflects a substantial contribution of DIC from oxidized organic matter (Liu et al., 2006; Chen et al., 2008), providing evidence of this reaction.

Sea ice during the Sturtian glaciation sharply reduced or terminated oxygen exchange between the atmosphere and the ocean-surface layer, leading to anoxic conditions within the Nanhua Basin watermass (Fig. 12A) (Li et al., 2012; Zhang et al., 2015). Owing to the solubility of Mn under reducing conditions (Roy, 2006; Maynard, 2003, 2014), this semi-restricted rift basin thus became a favorable site for accumulation of hydrothermally sourced $\mathrm{Mn}$. Extreme ${ }^{34} \mathrm{~S}$ enrichment of pyrite sulfur (+30 to $+60 \%$ ) within the overlying interglacial sediments indicates the formation of a highly evolved local sulfate pool with low sulfate concentrations at this time (Liu et al., 2006). Generally low sulfate availability provides evidence of the suppression of material exchanges between the ocean and land during the Sturtian glaciation (Li et al., 2012).

Conditions within the Nanhua Basin during the following interglacial interval 
favored Mn metallogenesis (Fig. 12B). After the Sturtian glaciation ended, enhanced continental weathering provided plentiful detritus, including nutrients, to the basin from Neoproterozoic continental flood basalts on the Yangtze Block ( $\mathrm{Li}$ and McCulloch, 1996; Wang et al., 2011; this study). Meanwhile, increased oxygenation of the ocean-surface layer (Zhang et al., 2015) led to a redox-stratified watermass within the Nanhua Basin ( $\mathrm{Li}$ et al., 2012). These conditions resulted in higher productivity in the surface water, leading to export of large amounts of organic matter to the deep basin. A large increase in the concentrations of pristane and phytane (from 0.016 to $0.087 \mathrm{ng} \mathrm{g}^{-1} \mathrm{C}$ ) at the top of the glacial succession underlying the Datangpo Formation indicates an enhanced photosynthetic process during the glacial-to-interglacial transition (Wang et al., 2008). Hydrothermally sourced nutrients may also have resulted in the addition to the sediment of considerable quantities of highly reactive microbial organic matter related to $\mathrm{Fe}^{2+}$ and $\mathrm{Mn}^{2+}$ enzymatic oxidation reactions. Additionally, microbial activities associated with the $\mathrm{Mn}^{2+}$ oxidation process and the reduction of Mn oxides during early diagenesis increased the organic carbon content of the sediment (Tebo et al, 2004; Morgan, 2005; Polgári et al., 2012a, b). The high TOC content (2-3\%) of the upper Tiesi'ao and lower Datangpo formations records this increased flux of organic carbon burial. Higher organic carbon burial fluxes created the conditions needed for reduction of Mn-oxides in the diagenetic environment and for generation of higher porewater alkalinity through microbial sulfate reduction and microbially mediated Mn reduction (Polgári et al., 2012a, b), leading to precipitation of secondary Mn-carbonates in abundance.

\section{Conclusions}

Elemental and Sr-Nd isotopic features of the Cryogenian-age Mn deposit in the lower Datangpo Formation of the Nanhua Basin indicate that two components dominate the composition of the Mn-ore and Mn-bearing shale. The siliciclastic component is characterized by low $\mathrm{La} / \mathrm{Sc}$ and $i^{87} \mathrm{Sr} /{ }^{86} \mathrm{Sr}$ ratios and high initial $\varepsilon \mathrm{Nd}(\mathrm{t})$ values, reflecting derivation through weathering of continental flood basalts. The 
Mn-carbonate component has high La/Sc and $i^{87} \mathrm{Sr} /{ }^{86} \mathrm{Sr}$ ratios and low initial $\varepsilon \mathrm{Nd}(\mathrm{t})$ values, reflecting a dominant hydrothermal source. The metallogenesis of the Datangpo Mn deposit is linked with the paleoseawater chemistry of the Cryogenian Nanhua Basin. During the Sturtian glaciation, hydrothermally sourced Mn accumulated in the anoxic watermass. During the post-Sturtian interglacial interval, a redox-stratified watermass developed, leading to precipitation of Mn-oxides in the deep basin through episodic ventilation by density flows. Co-burial of the Mn oxides with organic-rich sediments resulted in concurrent organic matter oxidation and precipitation of secondary Mn-carbonates owing to elevated porewater $\mathrm{Mn}^{2+}$ concentrations and alkalinity generated through microbial sulfate reduction and microbially mediated $\mathrm{Mn}$ reduction. The metallogenesis of the Datangpo Mn deposit shows similarities to processes of $\mathrm{Mn}$ accumulation in the modern Baltic Sea, although the hydrothermal source of Mn to the Dantagnpo Mn deposit shows similarities to the modern Red Sea.

\section{Acknowledgments}

We thank David J Bottjer for editorial handling and Márta Polgári and Nicolas Tribovillard for their constructive reviews of this manuscript. This research is supported by China Geological Survey (CGS) "Geological and Metallogenic Background in the Southeastern Margin of the Upper Yangtze Block (No. 12120114016701)" Project and Ministry of Land and Resources of the People's Republic of China "Deep Prospecting and Metallogenic System in the Southeastern Margin of the Upper Yangtze Block (No. 201411051)" Project. Research by TJA is supported by the U.S. National Science Foundation (Sedimentary Geology and Paleobiology program), the NASA Exobiology program, and the China University of Geosciences-Wuhan (SKL-GPMR program GPMR201301 and SKL-BGEG program BGL201407).

\section{References}

Amakawa, H., Ingri J., Masuda A., Shimizu, H., 1991. Isotopic compositions of Ce, 
$\mathrm{Nd}$ and $\mathrm{Sr}$ in ferromanganese nodules from the Pacific and Atlantic Oceans, the Baltic and Barents Seas, and the Gulf of Bothnia. Earth and Planetary Science Letters, 105, 554-565.

Algeo, T.J., Ingall, E., 2007. Sedimentary $\mathrm{C}_{\text {org }}: \mathrm{P}$ ratios, paleocean ventilation, and Phanerozoic atmospheric $\mathrm{pO}_{2}$. Palaeogeography, Palaeoclimatology, Palaeoecology 256, 130-155.

Anschutz, P., Blanc, G., Stille, P., 1995. Origin of fluids and the evolution of the Atlantis II deep hydrothermal system, Red Sea: Strontium isotope study. Geochimica et Cosmochimica Acta 59, 4799-4808.

Bühn, B., Stanistreet, I.G., Okrusch, M., 1992. Late Proterozoic outer shelf manganese and iron deposits at Otjosondu (Namibia) related to the Damaran oceanic opening. Economic Geology 87, 1393-1411.

Barovich, K., Foden, J., 2000. A Neoproterozoic flood basalt province in southern-central Australia: geochemical and $\mathrm{Nd}$ isotope evidence from basin fill. Precambrian Research 100, 213-234.

Bartlett, R., Mortimer, R.J.G., Morris, K.M., 2007. The biogeochemistry of a manganese-rich Scottish sea loch: Implications for the study of anoxic nitrification. Continental Shelf Research 27, 1501-1509.

Baturin, G.N., 1987. The Geochemistry of Manganese and Manganese Nodules in the Ocean. D. Reidel Publishing Company, Dordrecht, 342 pp.

Bau, M., Schmidt, K., Koschinsky, A., Hein, J., Kuhn, T., Usui, A., 2014. Discriminating between different genetic types of marine ferro-manganese crusts and nodules based on rare earth elements and yttrium. Chemical Geology 381, $1-9$.

Bonatti, E., 1975. Metallogenesis at oceanic spreading centers. Annual Review of Earth and Planetary Sciences 3, 401-431.

Boström, K., 1983. Genesis of ferromanganese deposits-diagnostic criteria for recent and old deposits. In: Rona, P.A. (Ed.), Hydrothermal Processes at Seafloor Spreading Centers. Springer, Berlin, pp. 473-489.

Bureau of Geology and Mineral Resources of Guizhou Province (BGMRGZP), 1987. 
Regional Geology of Guizhou Province, Geological Press House, Beijing (in Chinese with English abstract).

Burke, I.T., Kemp, A.E.S., 2002. Microfabric analysis of Mn-carbonate laminae deposition and Mn-sulfide formation in the Gotland Deep, Baltic Sea. Geochimica et Cosmochimica Acta 66, 1589-1600.

Butuzova, G.Y., Drits, V.A., Morozov, A.A., Gorschkov, A.I., 2009. Processes of formation of iron-manganese oxyhydroxides in the Atlantis-II and Thetis deeps of the Red Sea. In: Parnell, J., Ye, L.J., Chen, C.M. (Eds.), Sediment-Hosted Mineral Deposits. Blackwell, Oxford, pp. 57-72.

Cabral, A., Moore, J., Mapani, B., Koubová, M., Sattler, C.-D., 2011. Geochemical and mineralogical constraints on the genesis of the Otjosondu ferromanganese deposit, Namibia: hydrothermal exhalative versus hydrogenetic (including snowball-earth) origins. South African Journal of Geology 114, 57-76.

Calvert, S.E., Pedersen, T.F., 1996. Sedimentary geochemistry of manganese; implications for the environment of formation of manganiferous black shales. Economic Geology 91, 36-47.

Calvert, S.E., Price, N.B., 1970. Composition of manganese nodules and manganese carbonates from Loch Fyne, Scotland. Contributions to Mineralogy and Petrology 29, 215-233.

Chen, J., Jahn, B.-m., 1998. Crustal evolution of southeastern China: Nd and Sr isotopic evidence. Tectonophysics 284, 101-133.

Chen, X., Li, D., Ling, H.F., Jiang, S.Y., 2008. Carbon and sulfur isotopic compositions of basal Datangpo Formation, northeastern Guizhou, South China: Implications for depositional environment. Progress in Natural Science 18, 421-429.

Cocherie, A., Calvez, J.Y., Oudin-Dunlop, E., 1994. Hydrothermal activity as recorded by Red Sea sediments: Sr-Nd isotopes and REE signatures. Marine Geology 118, 291-302.

Dehler, C.M., Fanning, C.M., Link, P.K., Kingsbury, E.M., Rybczynski, D., 2010. Maximum depositional age and provenance of the Uinta Mountain Group and 
Big Cottonwood Formation, northern Utah: Paleogeography of rifting western Laurentia. Geological Society of America Bulletin 122, 1686-1699.

Del Rio-Salas, R., Ochoa-Landin, L., Eastoe, C.J., Ruiz, J., Meza-Figueroa, D., Valencia-Moreno, M., Zuniga-Hernandez, H., Zuniga-Hernandez, L., Moreno-Rodriguez, V., Mendivil-Quijada, H., 2013. Genesis of manganese oxide mineralization in the Boleo region and Concepcion Peninsula, Baja California Sur: constraints from $\mathrm{Pb}-\mathrm{Sr}$ isotopes and REE geochemistry. Revista Mexicana de Ciencias Geológicas 30, 482-499.

de Vries, S.T., Pryer, L.L., Fry, N., 2008. Evolution of Neoarchaean and Proterozoic basins of Australia. Precambrian Research 166, 39-53.

Dobrzinski, N., Bahlburg, H., Strauss, H., Zhang, Q., 2004. Geochemical climate proxies applied to the Neoproterozoic glacial succession on the Yangtze Platform, South China. In: Jenkins, G.S., McMenamin, M.A.S., McKay, C.P., Sohl, L. (Eds.), The Extreme Proterozoic: Geology, Geochemistry, and Climate, American Geophysical Union Geophysical Monograph Series 146, pp. 13-32.

Doe, B., Ayuso, R., Futa, K., Peterman, Z., 1996. Evaluation of the sedimentary manganese deposits of Mexico and Morocco for determining lead and strontium isotopes in ancient seawater. In: Basu, A., Hart, S. (Eds.), Earth Processes: Reading the Isotopic Code, American Geophysical Union Geophysical Monograph Series 95, pp. 391-408.

El Rhazi, M., Hayashi, K.-i., 2003. Origin and formational environment of Noda-Tamagawa manganese ore, northeast Japan: constraints from isotopic studies. Chemie der Erde—Geochemistry 63, 149-162.

Eyles, N., Januszczak, N., 2004. 'Zipper-rift': a tectonic model for Neoproterozoic glaciations during the breakup of Rodinia after 750 Ma. Earth-Science Reviews 65, 1-73.

Feng, L.J., Chu, X.L., Huang, J., Zhang, Q.R., Chang, H.J., 2010. Reconstruction of paleo-redox conditions and early sulfur cycling during deposition of the Cryogenian Datangpo Formation in South China. Gondwana Research 18, 632-637. 
Force, E.R., Cannon, W.F., 1988. Depositional model for shallow-marine manganese deposits around black shale basins. Economic Geology 83, 93-117.

Frakes, L., Bolton, B.R., 1992. Effects of ocean chemistry, sea level, and climate on the formation of primary sedimentary manganese ore deposits. Economic Geology 87, 1207-1217.

Glasby, G., 2006. Manganese: predominant role of nodules and crusts. In: Schulz, H., Zabel, M. (Eds.), Marine Geochemistry. Springer, Berlin, pp. 371-427.

Goddéris, Y., Donnadieu, Y., Nédélec, A., Dupré, B., Dessert, C., Grard, A., Ramstein, G., François, L.M., 2003. The Sturtian 'snowball' glaciation: fire and ice. Earth and Planetary Science Letters 211, 1-12.

Gutzmer, J., Beukes, N.J., 1998. The manganese formation of the Neoproterozoic Penganga Group, India; revision of an enigma. Economic Geology 93, 1091-1102.

Halverson, G.P., Dudás, F.Ö., Maloof, A.C., Bowring, S.A., 2007. Evolution of the ${ }^{87} \mathrm{Sr} /{ }^{86} \mathrm{Sr}$ composition of Neoproterozoic seawater. Palaeogeography, Palaeoclimatology, Palaeoecology 256, 103-129.

Hein, J.R., Yeh, H.W., Gunn, S.H., Gibbs, A.E., Wang, C.-h., 1994. Composition and origin of hydrothermal ironstones from central Pacific seamounts. Geochimica et Cosmochimica Acta 58, 179-189.

Hoffman, P.F., 1999. The break-up of Rodinia, birth of Gondwana, true polar wander and the snowball Earth. Journal of African Earth Sciences 28, 17-33.

Hoffman, P.F., Schrag, D.P., 2002. The snowball Earth hypothesis: testing the limits of global change. Terra Nova 14, 129-155.

Huckriede, H., Meischner, D., 1996. Origin and environment of manganese-rich sediments within black-shale basins. Geochimica et Cosmochimica Acta 60, 1399-1413.

Klein, C., Ladeira, E.A., 2004. Geochemistry and mineralogy of Neoproterzoic banded iron-formations and some selected, siliceous manganese formations from the Urucum District, Mato Grosso Do Sul, Brazil. Economic Geology 99, 1233-1244. 
Lepland, A., Stevens, R.L., 1998. Manganese authigenesis in the Landsort Deep, Baltic Sea. Marine Geology 151, 1-25.

Li, C., Love, G.D., Lyons, T.W., Scott, C.T., Feng, L., Huang, J., Chang, H., Zhang, Q., Chu, X., 2012. Evidence for a redox stratified Cryogenian marine basin, Datangpo Formation, South China. Earth and Planetary Science Letters 331-332, 246-256.

Li, X.H., McCulloch, M.T., 1996. Secular variation in the Nd isotopic composition of Neoproterozoic sediments from the southern margin of the Yangtze Block: evidence for a Proterozoic continental collision in southeast China. Precambrian Research 76, 67-76.

Li, X.H., Li, Z.X., Zhou, H., Liu, Y., Kinny, P.D., 2002. U-Pb zircon geochronology, geochemistry and Nd isotopic study of Neoproterozoic bimodal volcanic rocks in the Kangdian Rift of South China: implications for the initial rifting of Rodinia. Precambrian Research 113, 135-154.

Li, X.H., Liu, D., Sun, M., Li, W., Liang, X., Liu, Y., 2004. Precise Sm-Nd and U-Pb isotopic dating of the supergiant Shizhuyuan polymetallic deposit and its host granite, SE China. Geological Magazine141, 225-231.

Li, Z.H., Evans, D.A.D., Halverson, G.P., 2013. Neoproterozoic glaciations in a revised global palaeogeography from the breakup of Rodinia to the assembly of Gondwanaland. Sedimentary Geology 294, 219-232.

Ling, W., Gao, S., Zhang, B., Li, H., Liu, Y., Cheng, J., 2003. Neoproterozoic tectonic evolution of the northwestern Yangtze craton, South China: implications for amalgamation and break-up of the Rodinia Supercontinent. Precambrian Research 122, 111-140.

Liu, T.B., Maynard, J.B., Alten, J., 2006. Superheavy S isotopes from glacier-associated sediments of the Neoproterozoic of south China: Oceanic anoxia or sulfate limitation? In: Kesler, S.E., Ohmoto, H. (Eds.), Evolution of Early Earth's Atmosphere, Hydrosphere, and Biosphere-Constraints from Ore Deposits, Geological Society of America Memoir 198, pp. 205-222.

Marchig, V., Gundlach, H., Möller, P., Schley, F., 1982. Some geochemical indicators 
for discrimination between diagenetic and hydrothermal metalliferous sediments. Marine Geology 50, 241-256.

Maynard, J.B., 2014. Manganiferous sediments, rocks, and ores. In MacKenzie, F.T., (Eds.), Treatise of Geochemistry 2nd edition. Vol. 9, Sediments, Diagenesis, and Sedimentary Rocks: Amsterdam, Elsevier, pp. 327-349.

Maynard, J.B., 2003. Manganiferous sediments, rocks, and ores. In: Holland, H.D., Turekian, K.K. (Eds.), Treatise of Geochemistry 2nd edition. Vol. 7, Sediments, Diagenesis, and Sedimentary Rocks: Pergamon, Oxford, pp. 289-308.

Morgan, J.J., 2005. Kinetics of reaction between $\mathrm{O}_{2}$ and $\mathrm{Mn}(\mathrm{II})$ species in aqueous solutions. Geochimica et Cosmochimica Acta 69, 35-48.

Murray, J.W., Tebo, B.M., 1991. Black Sea Oceanography: Results from the 1988 Black Sea Expedition. Manganese(II) oxidation in the suboxic zone of the Black Sea. Deep Sea Research Part A. Oceanographic Research Papers 38, S883-S905.

Nesbitt, H.W., Young, G.M., 1982. Early Proterozoic climates and plate motions inferred from major element chemistry of lutites. Nature 299(5885), 715-717.

Neumann, T., Christiansen, C., Clasen, S., Emeis, K.C., Kunzendorf, H., 1997. Geochemical records of salt-water inflows into the deep basins of the Baltic Sea. Continental Shelf Research 17, 95-115.

Neumann, T., Heiser, U., Leosson, M.A., Kersten, M., 2002. Early diagenetic processes during Mn-carbonate formation: evidence from the isotopic composition of authigenic Ca-rhodochrosites of the Baltic Sea. Geochimica et Cosmochimica Acta 66, 867-879.

Nicholson, K., 1992. Contrasting mineralogical-geochemical signatures of manganese oxides; guides to metallogenesis. Economic Geology 87, 1253-1264.

Nicholson, K., Nayak, V.K., Nanda, J.K., 1997. Manganese ores of the Ghoriajhor-Monmunda area, Sundergarh District, Orissa, India: geochemical evidence for a mixed Mn source. In: Nicholson, K. (Ed.), Manganese Mineralization: Geochemistry and Mineralogy of Terrestrial and Marine Deposits, Geological Society of London Special Publication 119, pp. 117-121.

Okita, P.M., Shanks, W.C., III, 1992. Origin of stratiform sediment-hosted manganese 
carbonate ore deposits: Examples from Molango, Mexico, and TaoJiang, China. Chemical Geology 99, 139-163.

Pedersen, T.F., Price, N.B., 1982. The geochemistry of manganese carbonate in Panama Basin sediments. Geochimica et Cosmochimica Acta 46, 59-68.

Peter, J.M., Goodfellow, W.D., 1996. Mineralogy, bulk and rare earth element geochemistry of massive sulphide-associated hydrothermal sediments of the Brunswick Horizon, Bathurst Mining Camp, New Brunswick. Canadian Journal of Earth Science 33, 252-283.

Polgári, M., Hein, J.R., Vigh, T., Szabó-Drubina, M., Fórizs, I., Bíró, L., Müller, A., Tóth, A.L., 2012a. Microbial processes and the origin of the Úrkút manganese deposit, Hungary. Ore Geology Reviews 47, 87-109.

Polgári, M., Hein, J.R., Tóth, A.L., Pál-Molnár, E., Vigh, T., Bíró, L., Fintor, K., 2012b. Microbial action formed Jurassic Mn-carbonate ore deposit in only few hundred years (Úrkút, Hungary). Geology 40, 903-906.

Polgári, M., Hein, J.R., Németh, T., Pál-Molnár, E., Vígh T., 2013. Celadonite and smectite formation in the Úrkút Mn-carbonate ore deposit (Hungary). Sedimentary Geology 294, 157-163.

Polgári, M., Németh, T., Pál-Molnár, E., Futó, I., Vígh, T., Mojzsis, S.J., 2016. Correlated chemostratigraphy of Mn-carbonate microbialites (Úrkút, Hungary). Gondwana Research 29, 278-289.

Preiss, W.V., 2000. The Adelaide Geosyncline of South Australia and its significance in Neoproterozoic continental reconstruction. Precambrian Research 100, 21-63.

Rooney, A.D., Macdonald, F.A., Strauss, J.V., Dudás, F.Ö., Hallmann, C., Selby, D., 2014. Re-Os geochronology and coupled Os-Sr isotope constraints on the Sturtian snowball Earth. Proceedings of the National Academy of Sciences (U.S.A.) 111, 51-56.

Roy, S., 2006. Sedimentary manganese metallogenesis in response to the evolution of the Earth system. Earth-Science Reviews 77, 273-305.

Roy, S., Bandopadhyay, P. C., Perseil, E. A., Fukuoka, M., 1990. Late diagenetic changes in manganese ores of the Upper Proterozoic Penganga Group, India. Ore 
Geology Reviews 5, 341-357.

Rudnick, R., Gao, S., 2003. Composition of the continental crust. In: Holland, H.D., Turekian, K.K. (Eds.), The Crust, vol. 3, Treatise on Geochemistry, Pergamon, Oxford, pp. 1-64.

Schmidt, M., Botz, R., Faber, E., Schmitt, M., Poggenburg, J., Garbe-Schönberg, D., Stoffers, P., 2003. High-resolution methane profiles across anoxic brine-seawater boundaries in the Atlantis-II, Discovery, and Kebrit Deeps (Red Sea). Chemical Geology 200, 359-375.

Shields-Zhou, G.A., Hill, A.C., Macgabhann, B.A., 2012. The Cryogenian Period. In: Gradstein, F.M., Ogg, J.G., Schmitz, M., Ogg, G. (Eds.), The Geologic Time Scale. Elsevier, Amsterdam, pp. 393-411.

Sternbeck, J., Sohlenius, G., 1997. Authigenic sulfide and carbonate mineral formation in Holocene sediments of the Baltic Sea. Chemical Geology 135, 55-73.

Stille, P., Clauer, N., Abrecht, J., 1989. Nd isotopic composition of Jurassic Tethys seawater and the genesis of Alpine Mn-deposits: Evidence from $\mathrm{Sr}-\mathrm{Nd}$ isotope data. Geochimica et Cosmochimica Acta 53, 1095-1099.

Tang, S., Liu, T., 1999. Origin of the early Sinian Minle manganese deposit, Hunan Province, China. Ore Geology Reviews 15, 71-78.

Taylor, S.R., McLennan, S.M., 1985. The Continental Crust: Its Composition and Evolution. Blackwell, Oxford, 312 pp.

Tebo, B.M., Bargar, J.R.. Clement, B., Dick, G., Murray, K.J., Parker, D., Verity, R., Webb, S., 2004. Manganese biooxide: properties and mechanisms of formation. Annual Review of Earth and Planetary Sciences 32, 287-328.

Thamdrup, B., Rosselló-Mora, R., Amann, R., 2000. Microbial manganese and sulfate reduction in Black Sea shelf sediments. Applied Environmental Microbiology 66, 2888-2897.

Thomson, D., Rainbird, R.H., Krapez, B., 2015. Sequence and tectonostratigraphy of the Neoproterozoic (Tonian-Cryogenian) Amundsen Basin prior to supercontinent (Rodinia) breakup. Precambrian Research 263, 246-259.

Tribovillard, N., Algeo, T.J., Lyons, T., Riboulleau, A., 2006. Trace metals as 
paleoredox and paleoproductivity proxies: an update. Chemical Geology 232, 12-32.

Wang, J., Li, Z.X., 2003. History of Neoproterozoic rift basins in South China: implications for Rodinia break-up. Precambrian Research 122, 141-158.

Wang, T.-G., Li, M., Wang, C., Wang, G., Zhang, W., Shi, Q., Zhu, L., 2008. Organic molecular evidence in the Late Neoproterozoic tillites for a palaeo-oceanic environment during the Snowball Earth era in the Yangtze region, southern China. Precambrian Research 162, 317-326.

Wang, X.C., Li, Z.X., Li, X.H., Li, Q.L., Zhang, Q.R., 2011. Geochemical and Hf-Nd isotope data of Nanhua rift sedimentary and volcaniclastic rocks indicate a Neoproterozoic continental flood basalt provenance. Lithos 127, 427-440.

Weber, F., 1997. Evolution of lateritic manganese deposits. In: Paquet, H., Clauer, N. (Eds.), Soils and Sediments: Mineralogy and Geochemistry, Springer Berlin, pp. 97-124.

Xu, X., Huang, H., Liu, B., 1990. Manganese deposits of the Proterozoic Datangpo Formation, South China: genesis and palaeogeography. In: Parnell, J., Ye, L.J., Chen, C.M. (Eds.), Sediment-Hosted Mineral Deposits, Blackwell, Oxford, pp. $39-49$.

Yang, J., Tao, X., Xue, Y., 1997. Nd isotopic variations of Chinese seawater during Neoproterozoic through Cambrian. Chemical Geology 135, 127-137.

Zhang, F., Zhu, X., Yan, B., Kendall, B., Peng, X., Li, J., Algeo, T.J., Romaniello, S., 2015. Oxygenation of a Cryogenian ocean (Nanhua Basin, South China) revealed by pyrite Fe isotope compositions. Earth and Planetary Science Letters 429, $11-19$.

Zhang, S., Jiang, G., Han, Y., 2008. The age of the Nantuo Formation and Nantuo glaciation in South China. Terra Nova 20, 289-294.

Zheng, Y.F., Zhang, S.B., Zhao, Z.F., Wu, Y.B., Li, X., Li, Z., Wu, F.-Y., 2007. Contrasting zircon $\mathrm{Hf}$ and $\mathrm{O}$ isotopes in the two episodes of Neoproterozoic granitoids in South China: Implications for growth and reworking of continental crust. Lithos 96, 127-150. 
Zhou, C., Tucker, R., Xiao, S., Peng, Z., Yuan, X., Chen, Z., 2004. New constraints on the ages of Neoproterozoic glaciations in south China. Geology 32, 437-440.

Zhou, J.C., Wang, X.L., Qiu, J.S., 2009. Geochronology of Neoproterozoic mafic rocks and sandstones from northeastern Guizhou, South China: Coeval arc magmatism and sedimentation. Precambrian Research 170, 27-42.

Zhou, Q., Du, Y.S., Yuan, L.J., Zhang, S., Yu, W.C., Yang, S.T., Yu, L., 2016. Rift basin structure and its control function in Nanhua period of Guizhou-Hunan-Chongqing border area. Journal of Earth Science (China University of Geosciences-Wuhan) (in Chinese with English abstract), in press. 


\section{Figure captions}

Fig. 1. (A) Global paleogeographic reconstruction at $\sim 660 \mathrm{Ma}$ (modified from Li et al., 2013). (B) Location of drillcore ZK4207 within the Late Neoproterozoic Nanhua Rift Basin of South China (modified from Wang and Li, 2003).

Fig. 2. (A) Detailed paleogeography of the study area. (B) Cross-section showing thicknesses of Sturtian and post-Sturtian ( 665-655 Ma) sedimentary units. Stratal data, including the distribution of Mn ore zones, are from BGMRGZP (1987), Zhou et al. (2016), and fieldwork by the first author. Note location of drillcore ZK4207 between points ' $g$ ' and ' $h$ '.

Fig. 3. Depositional models for manganese carbonate deposits in stratified anoxic basins. (A) Bathtub ring model, modified from Force and Cannon (1988). (B) Episodic ventilation model, modified from Huckriede and Meischner (1996).

Fig. 4. (A) Lithological column and sample locations for drillcore ZK4207; (B) Profiles of TOC and molar $\mathrm{C}_{\mathrm{org}}: \mathrm{P}$ ratios in the upper Tiesi'ao and lower Datangpo formations. In the $\mathrm{C}_{\mathrm{org}}: \mathrm{P}$ profile, the black line represents measured TOC and the red line represents TOC corrected for oxidation linked to Mn reduction. Redox fields are adapted from Algeo and Ingall (2007).

Fig. 5. (A) Spherical crystals of rhodochrosite (ZK 4207-4, 40X); (B) Mn carbonate minerals in the Mn ore (ZK 4207-21, 60X); (C); (D) Main minerals of the Mn ore (ZK 4207-4, 100X). (E) Rhodochrosite crystals (ZK 4207-21, 200 X); (F) EDS analysis of rhodochrosite crystal. A is plane-light thin-section images and B-E are SEM images. Rds - rhodochrosite; Qtz - quartz; Py - pyrite; Fsp - feldspar.

Fig. 6. Mn versus (A) $\mathrm{Al}_{2} \mathrm{O}_{3}$, (B) $\mathrm{SiO}_{2}$, (C) initial ${ }^{87} \mathrm{Sr} /{ }^{86} \mathrm{Sr}$ and (E) initial $\varepsilon N d(t)$, and 
$\mathrm{Al}_{2} \mathrm{O}_{3}$ versus (D) initial ${ }^{87} \mathrm{Sr} /{ }^{86} \mathrm{Sr}$ and (F) initial $\varepsilon N d(t)$. Samples for which REE patterns were shown in Figure 7 are indicated with gray shadows.

Fig. 7. Upper continental crust (UCC)-normalized REE patterns of samples from (A) $1^{\text {st }}$ Member of the Datangpo Formation, (B) $2^{\text {nd }}$ Member of the Datangpo Formation, and (C) other units. UCC data are from Rudnick and Gao (2003). The colored fields in A and B represent large sets of samples between the extremes (shown by discrete lines).

Fig. 8. Initial ${ }^{87} \mathrm{Sr} /{ }^{86} \mathrm{Sr}$ and initial $\varepsilon N d(\mathrm{t})$. Samples for which REE patterns were shown in Fig. 7 are indicated with gray shadows.

Fig. 9. Initial ${ }^{87} \mathrm{Sr} /{ }^{86} \mathrm{Sr}$ and $\varepsilon_{\mathrm{Nd}}(\mathrm{t})$ ratios of $\mathrm{Mn}$ deposits of various ages. Sources: Pennine Alps (Stille et al., 1989); Molango (Doe et al., 1996); Red Sea (Cocherie et al., 1994); Baltic Sea (Amakawa et al., 1991). Dashed lines for each deposit indicate ${ }^{87} \mathrm{Sr} /{ }^{86} \mathrm{Sr}$ values of coeval seawater.

Fig. 10. (A) $\mathrm{Nd} \mathrm{T}_{\mathrm{DM}}$ ages and (B) initial $\varepsilon \mathrm{Nd}(\mathrm{t})$ versus stratigraphic ages $\left(\mathrm{T}_{\text {strat }}\right)$ of study samples compared with secular trends for sedimentary rocks of the Nanhua Rift Basin, South China (green and blue curves; Li and McCulloch, 1996) and the Adelaide Rift Complex and Amadeus and Officer basins in Australia (red curve; Wang et al., 2011). (C) Late Neoproterozoic and Early Cambrian seawater initial $\varepsilon N d(t)$ for South China (Yang et al., 1997). (D) Initial $\varepsilon N d(t)$ versus $\mathrm{La} / \mathrm{Sc}$ of study samples; the dashed line represents a mixing trend between mafic and felsic endmembers, and the yellow field represents $\sim 825-750-\mathrm{Ma}$ basaltic rocks in South China (Wang et al., 2011). In D, ratios of elements with different levels of incompatibility are useful in characterizing two-component mixing systems (Taylor and McLennan, 1985). Note that only samples from the $1^{\text {st }}$ Member of the Datangpo Formation are shown in this figure. The legend in A applies to all panels. 
Fig. 11. Discriminant plots of sediments with hydrothermal and hydrogenous origins. (A) $\mathrm{Eu} / \mathrm{Eu}^{*}$ versus $\mathrm{Mn}$ (Peter and Goodfellow, 1996). (B) $\mathrm{Y} / \mathrm{P}_{2} \mathrm{O}_{5}$ versus $\mathrm{Zr} / \mathrm{Cr}$ (Marchig et al., 1982). (C) $\mathrm{Fe} / \mathrm{Ti}$ versus $\mathrm{Al} /(\mathrm{Al}+\mathrm{Fe}+\mathrm{Mn})$; the line shows percent hydrothermal composition (Marchig et al., 1982; Boström, 1983). (D) $\mathrm{SiO}_{2}$ versus $\mathrm{Al}_{2} \mathrm{O}_{3}$ (Bonatti, 1975).

Fig. 12. Metallogenesis model for the Datangpo Mn-ore deposit in the Nanhua Basin, South China. 


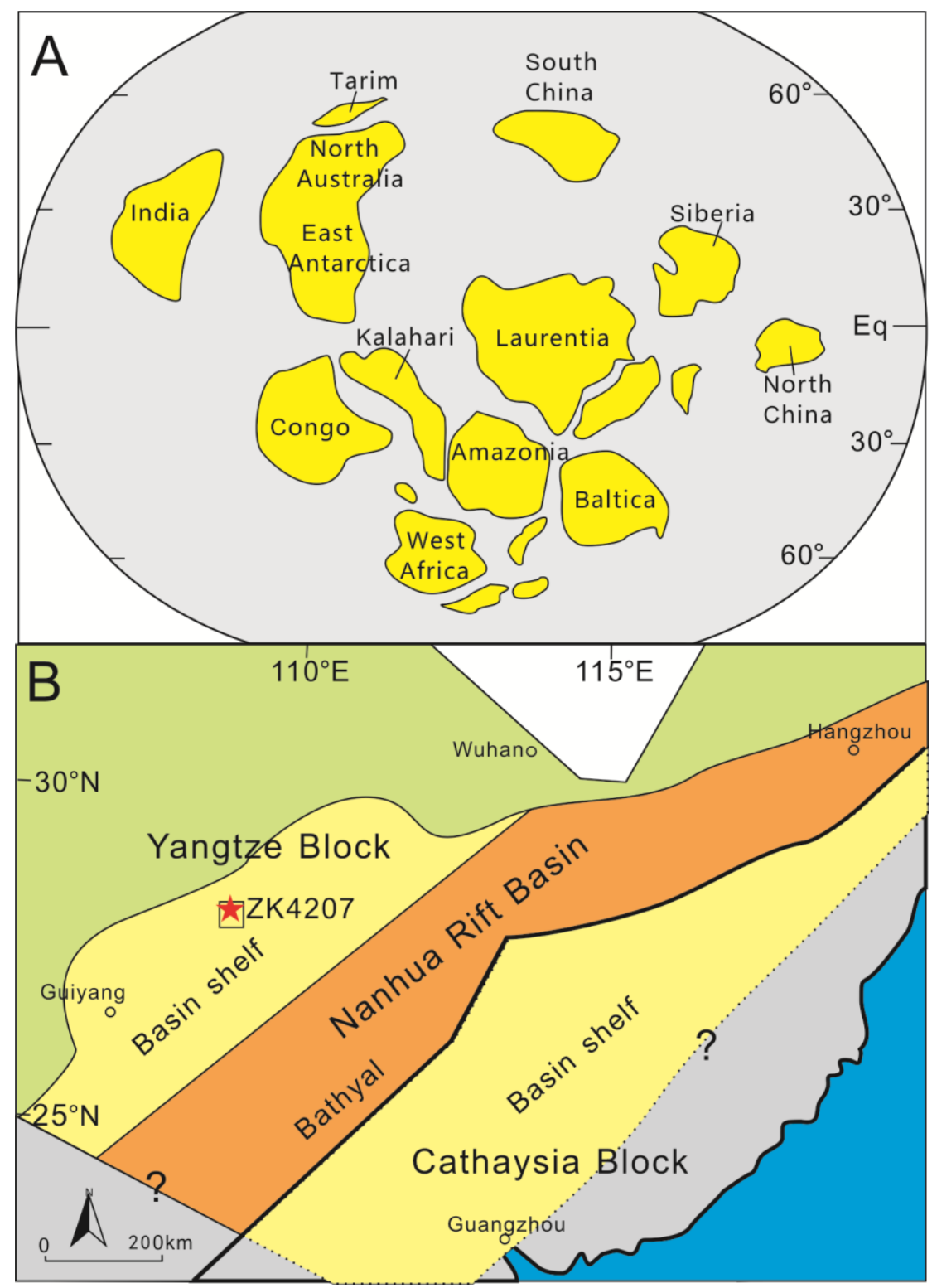

Figure 1 

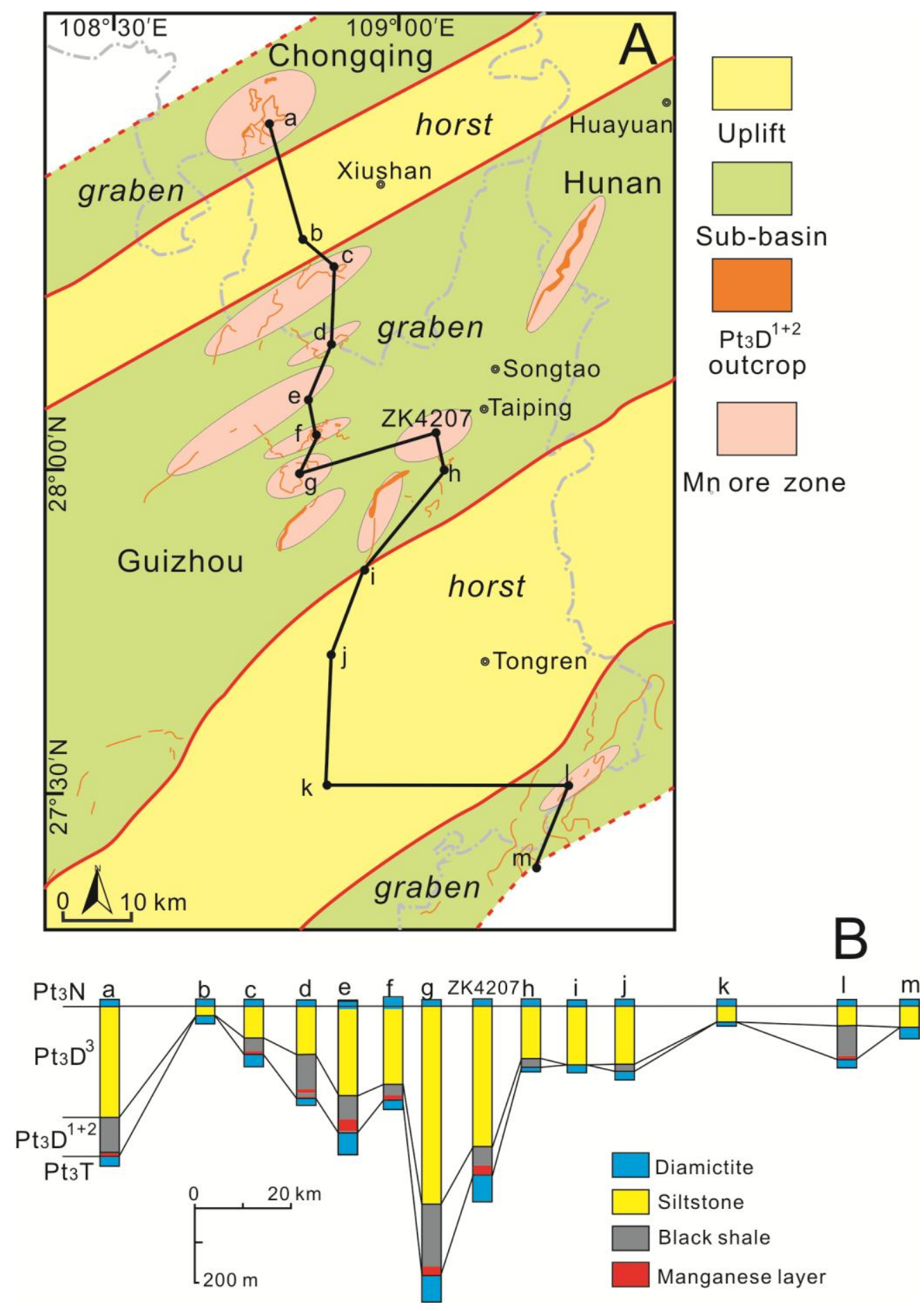

Figure 2 

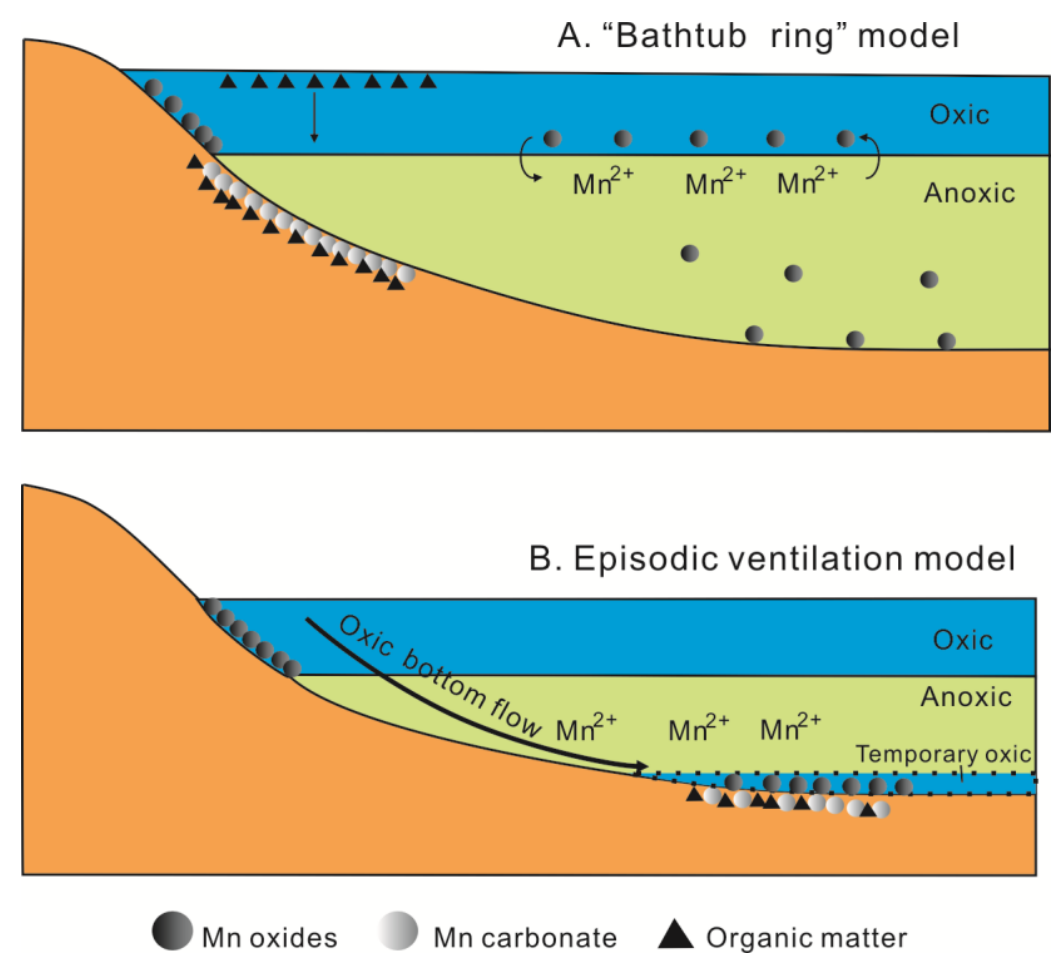

Figure 3 


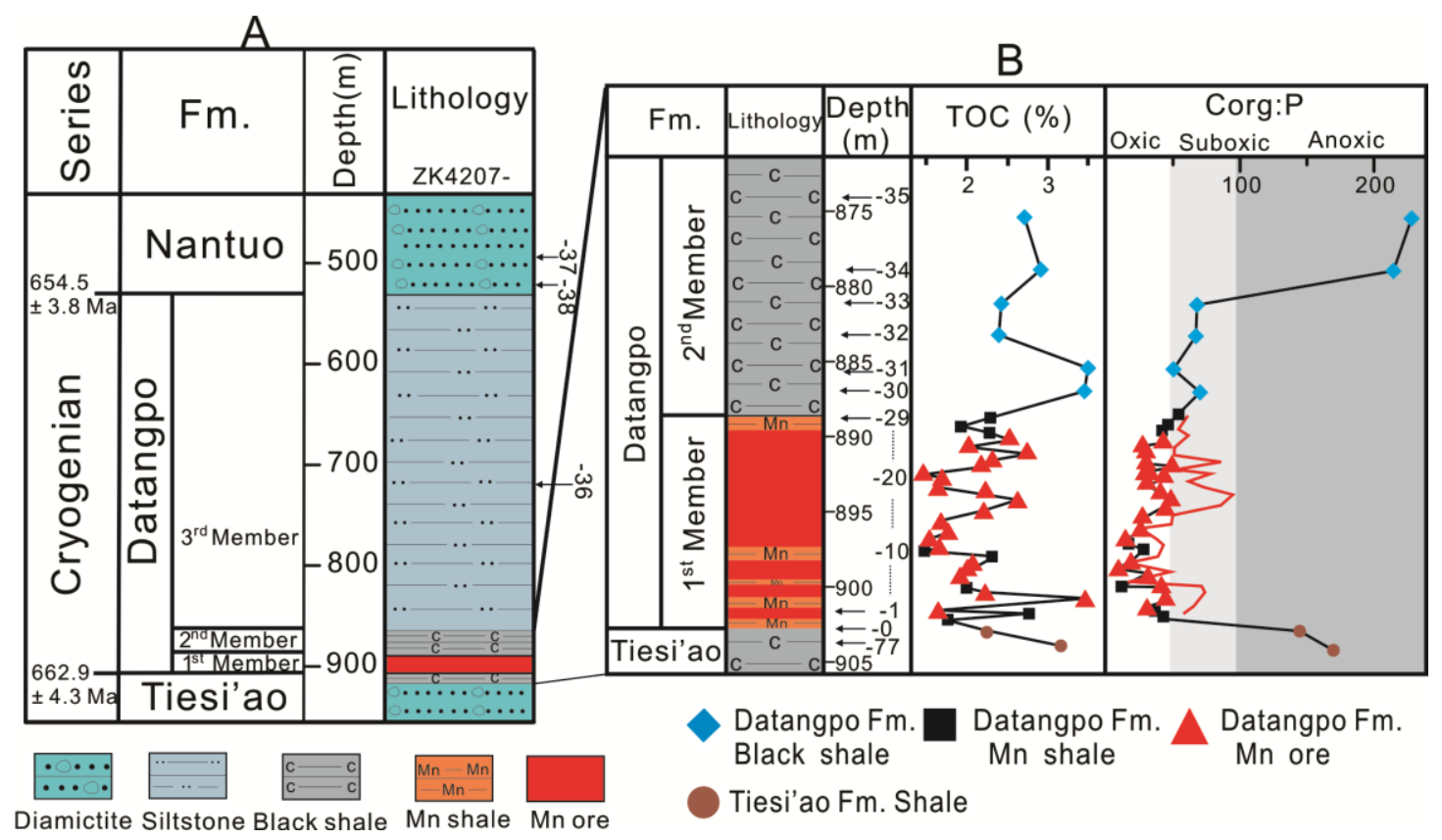

Figure 4 

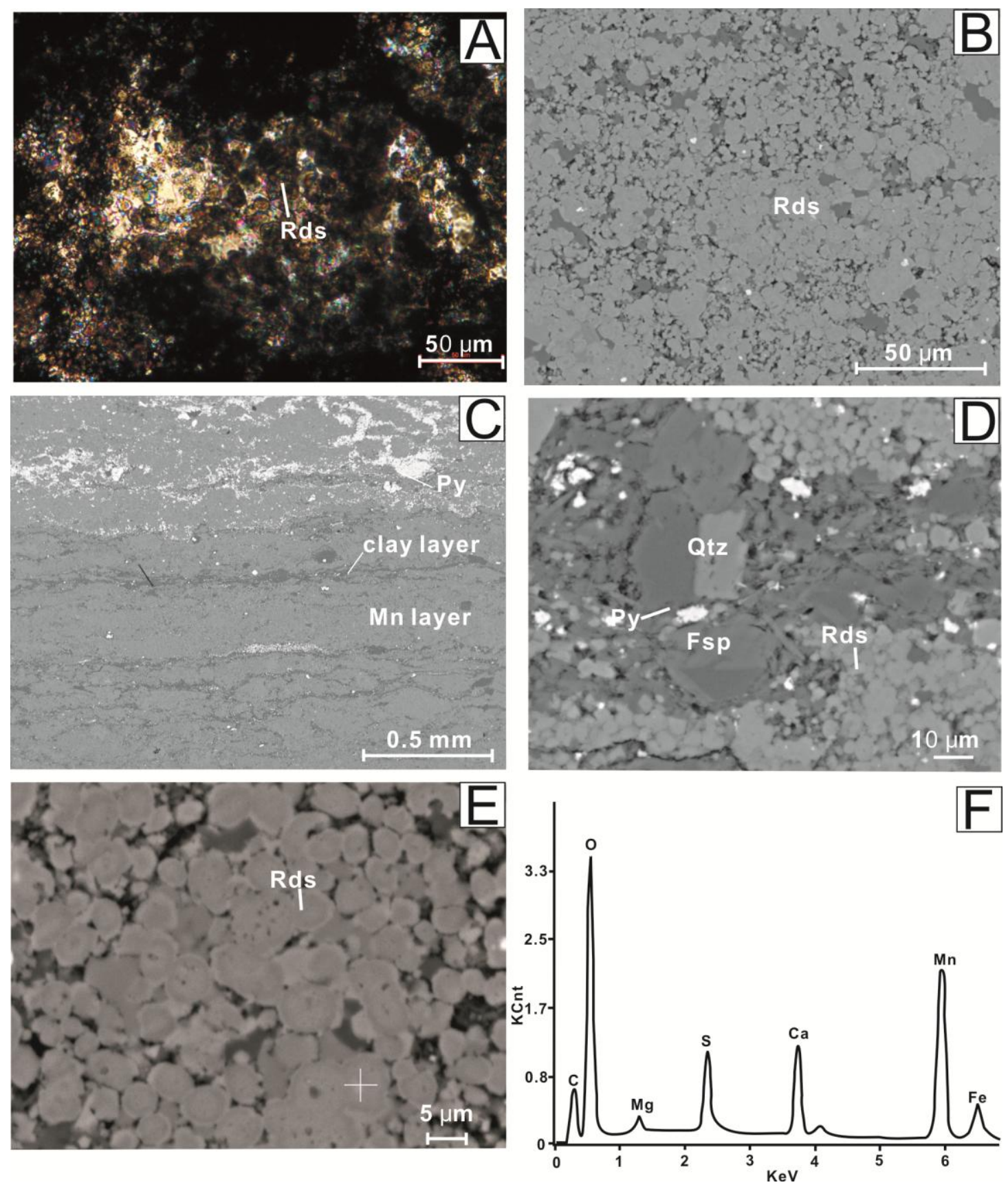

Figure 5 

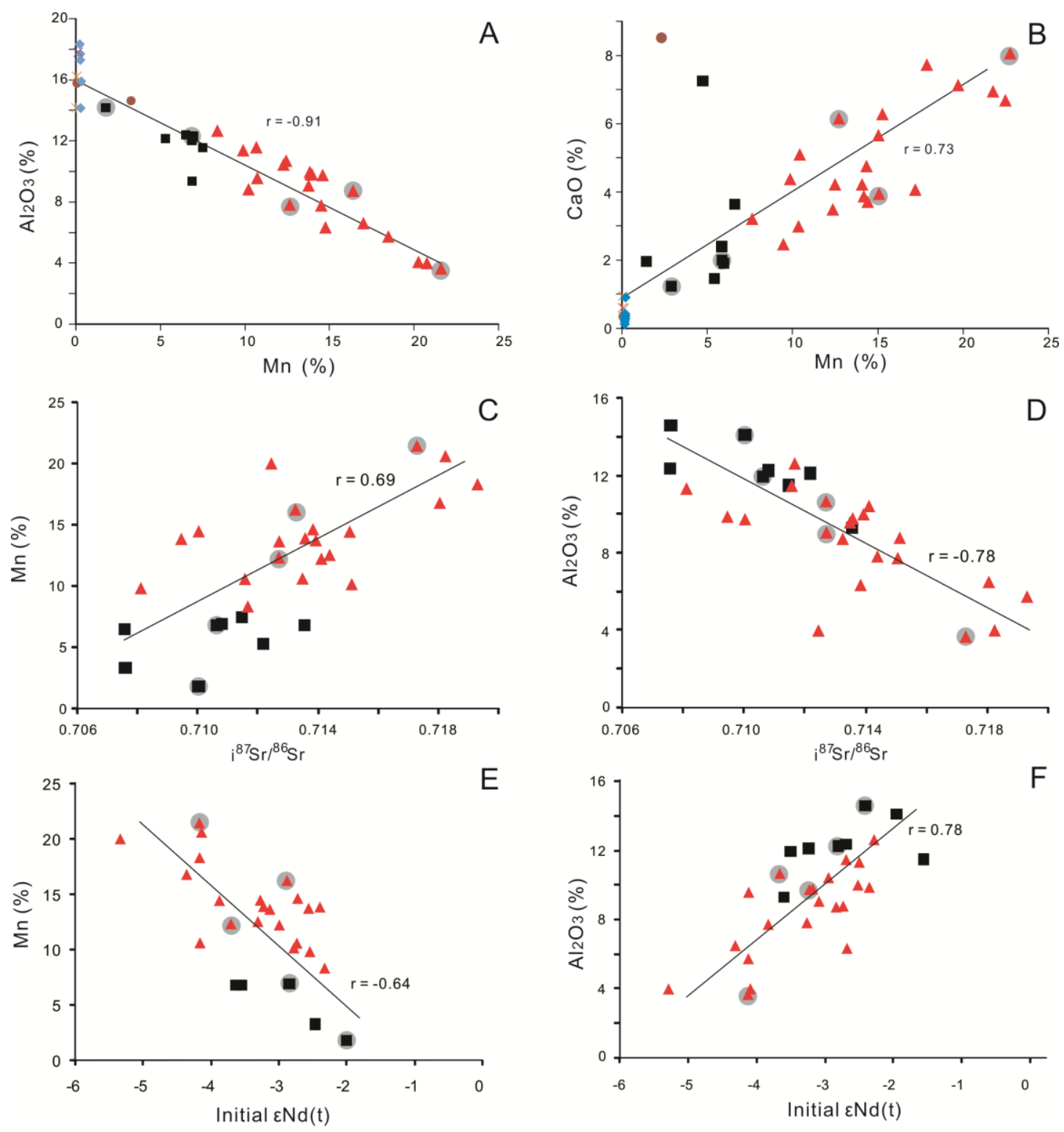

* Nantuo Fm. X Datangpo Fm. $\begin{gathered}\text { Datangpo Fm } \\ \text { Siltstone }\end{gathered}$ Black shale

Datangpo Fm. Datangpo Fm. Tiesi'ao Fm. Shale $\mathrm{Mn}$ shale $\mathrm{Mn}$ ore

Figure 6 


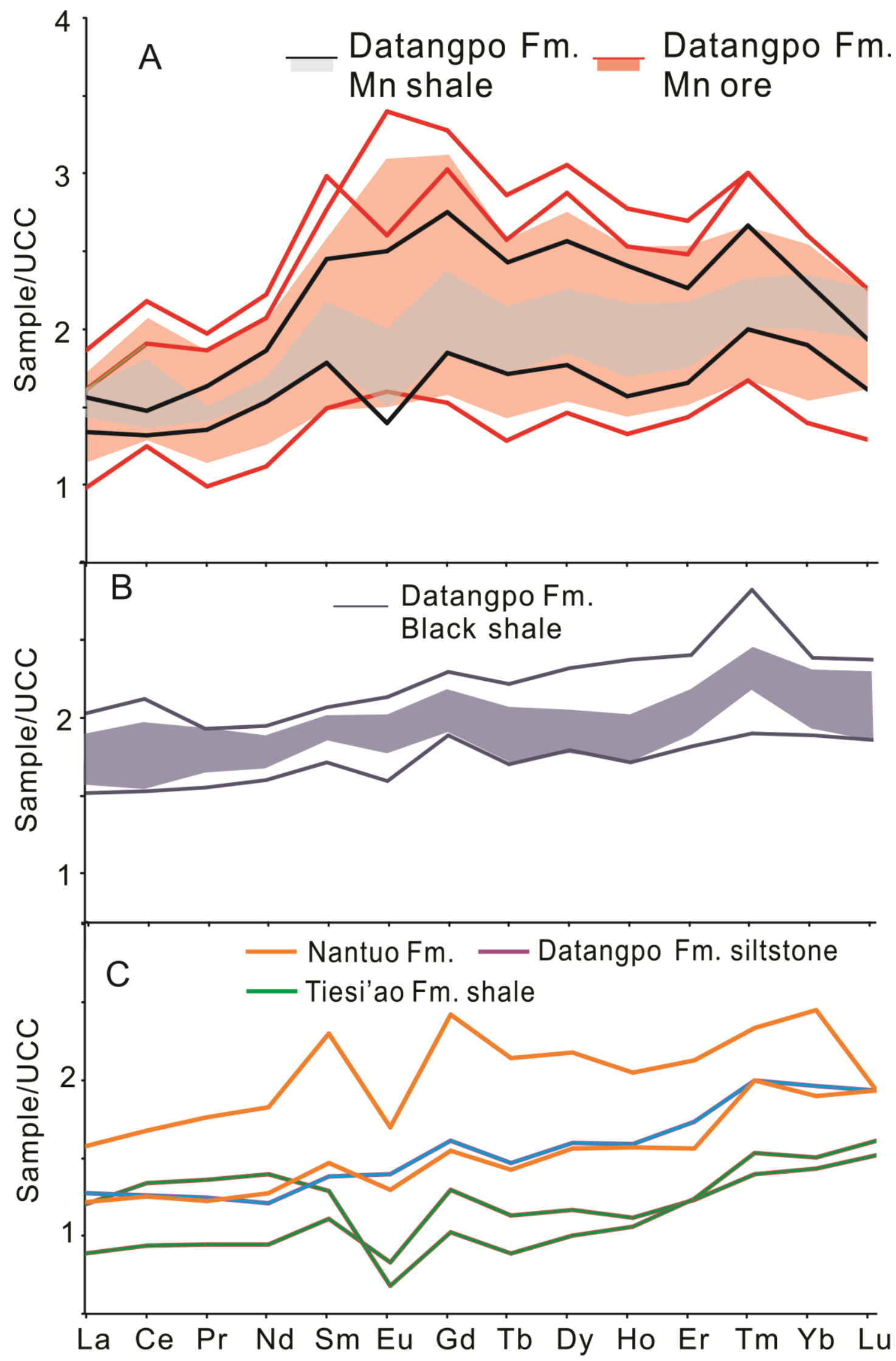
Figure 7 


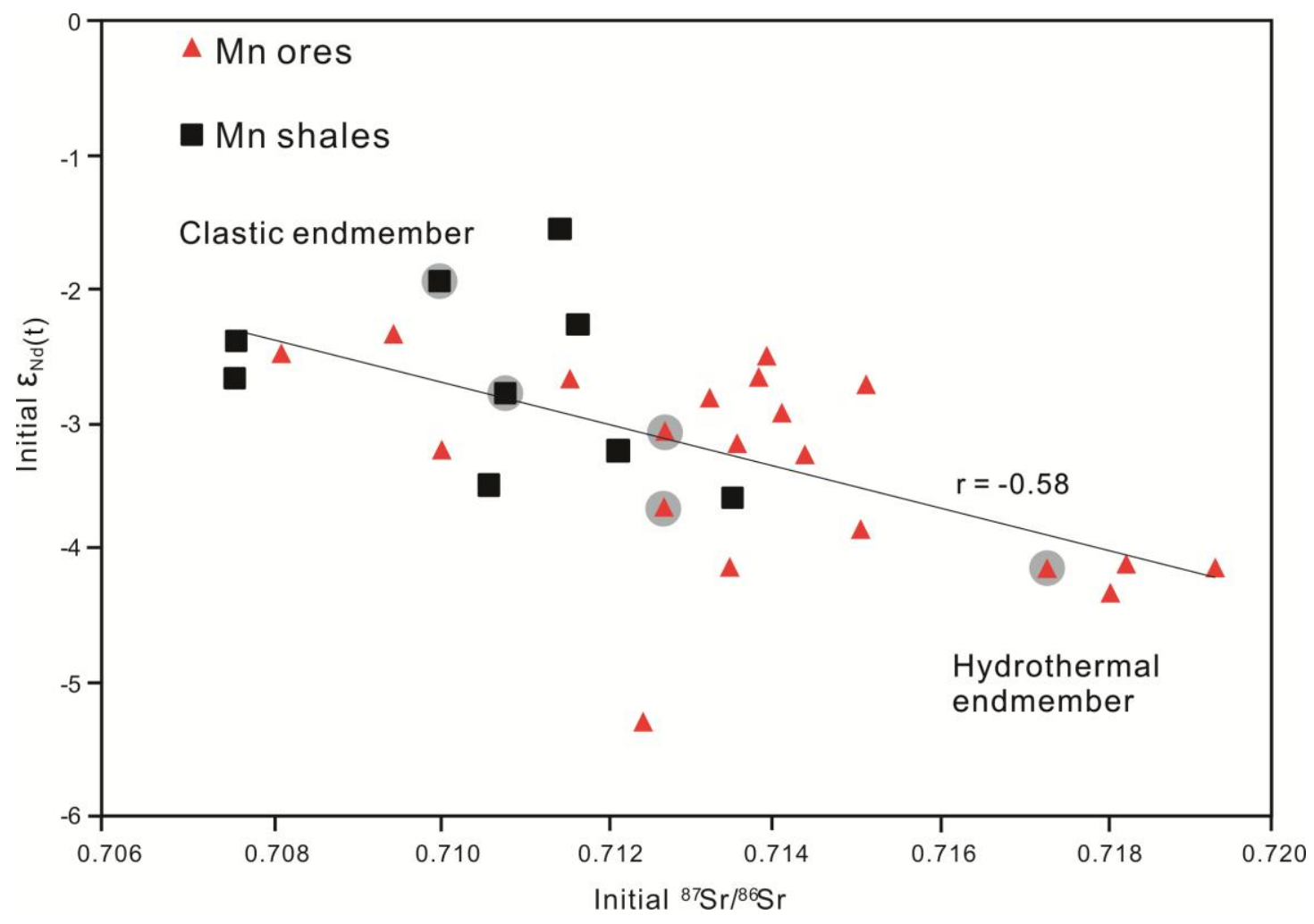

Figure 8 


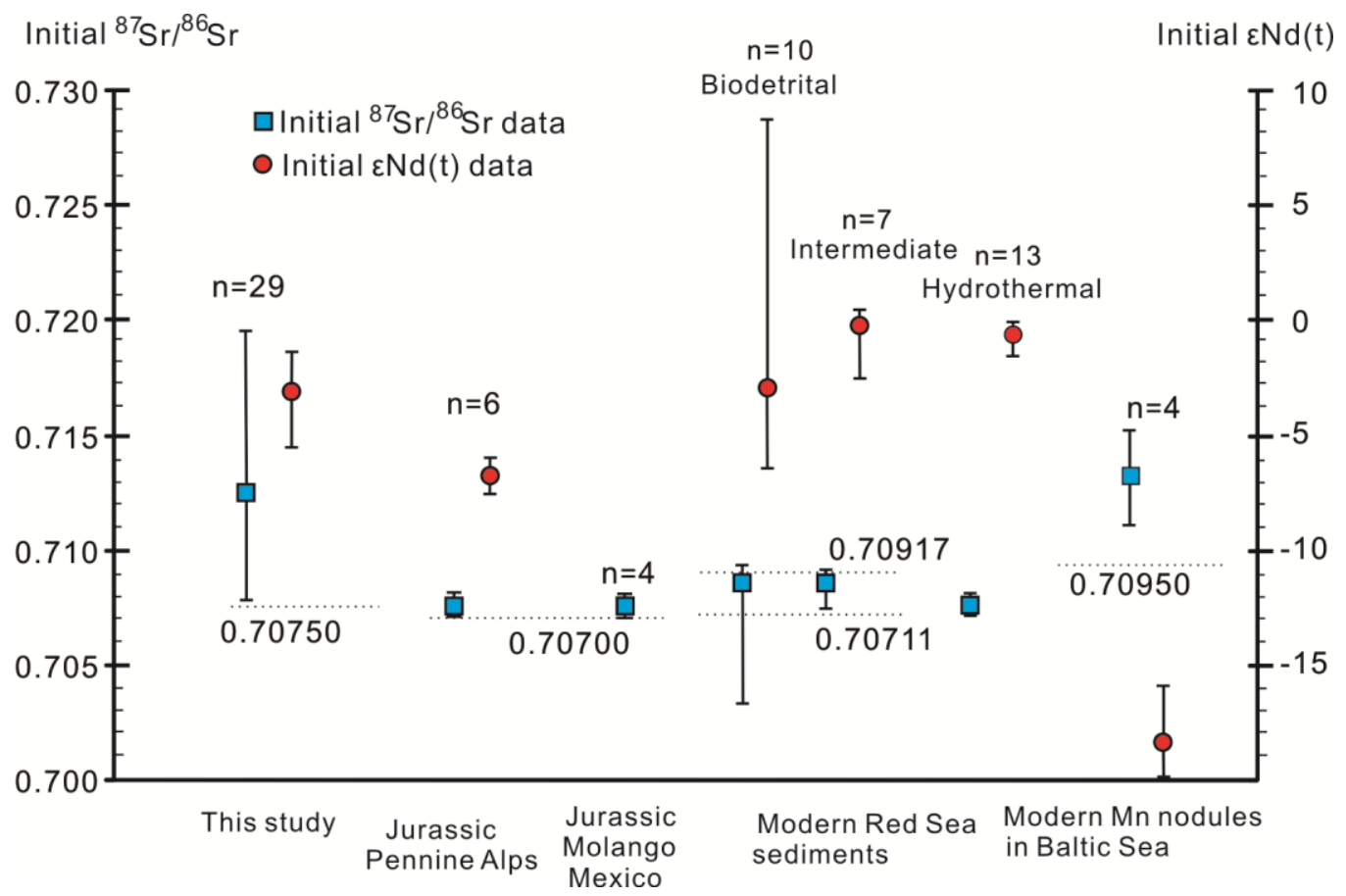

Figure 9 

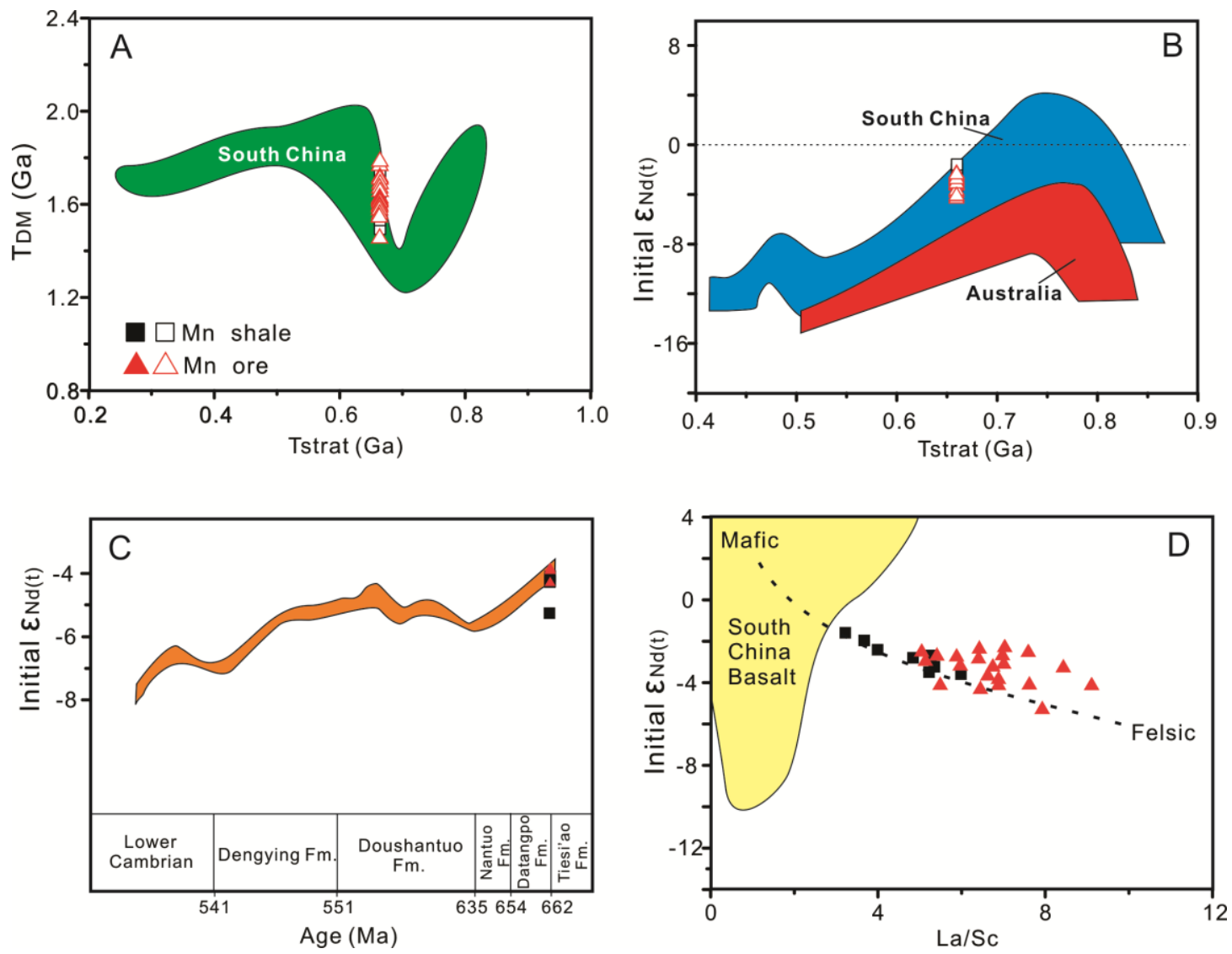

Figure 10 

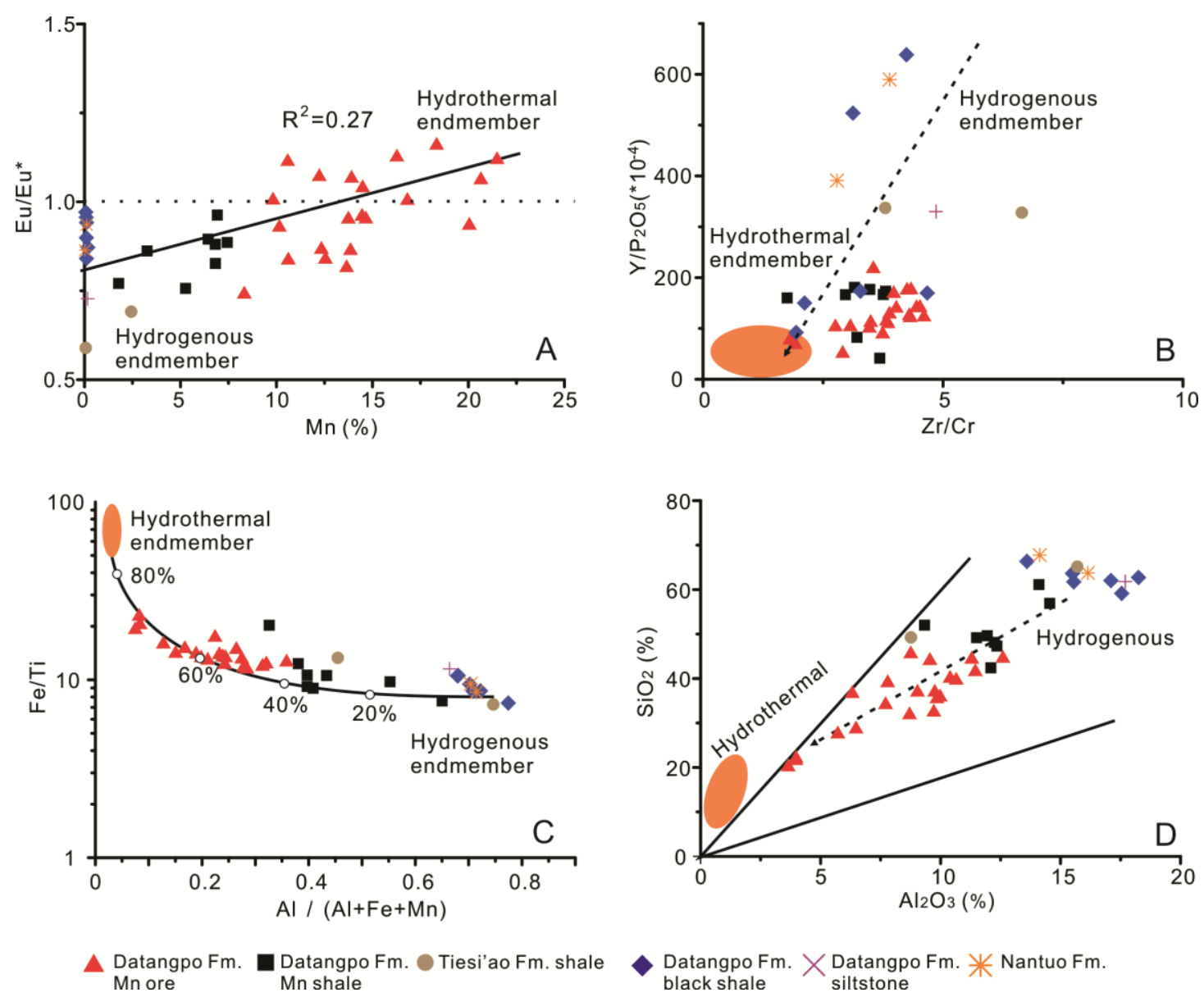

Figure 11 


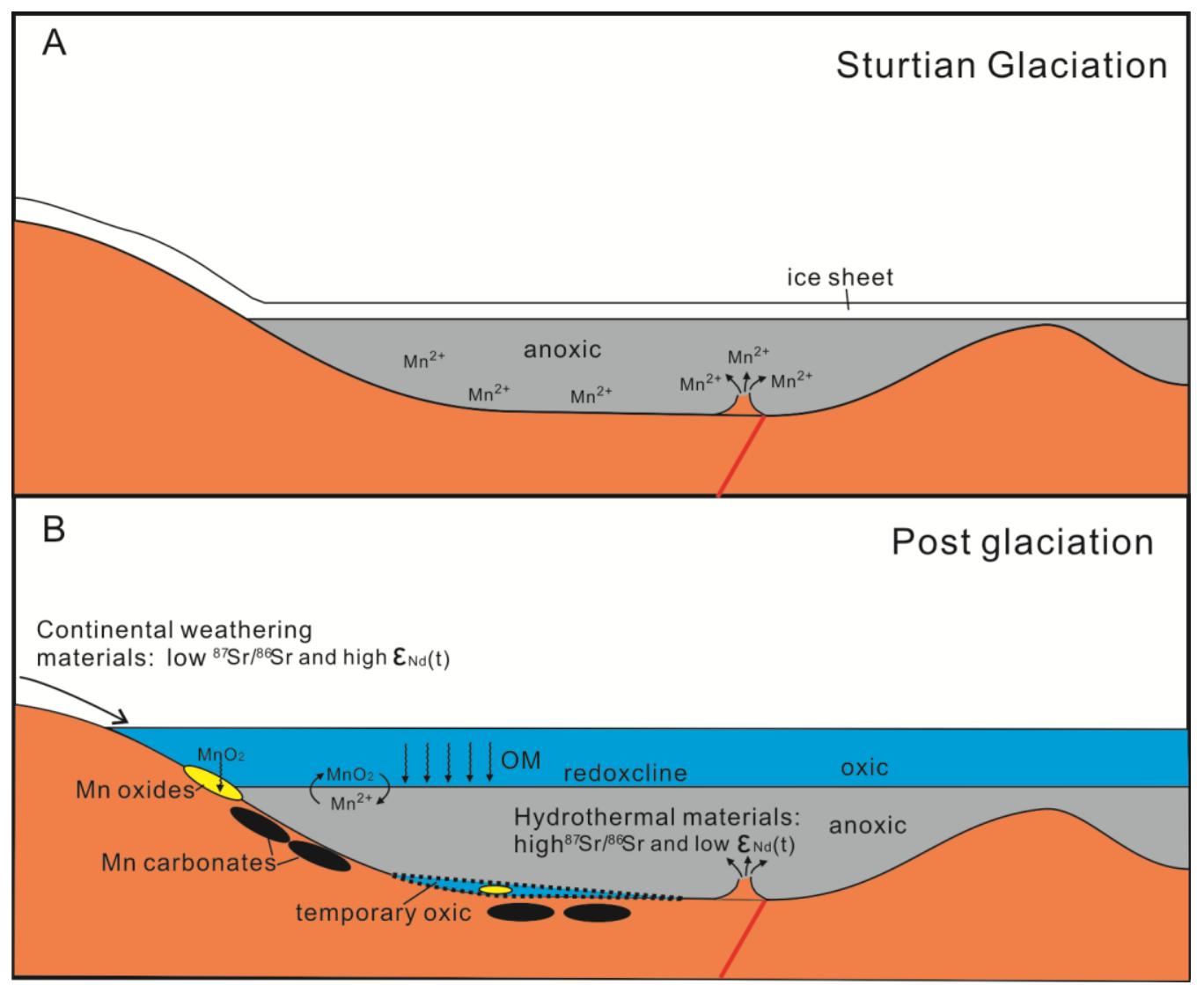

Figure 12 
Table 1. Mineralogical composition of the 1st Member of the Datangpo Formation in drillsite ZK4207 based on XRD data

\begin{tabular}{|c|c|c|c|c|c|c|c|c|}
\hline Fm. & Sample & $\begin{array}{l}\text { Depth } \\
\mathrm{m}\end{array}$ & $\begin{array}{c}\text { Quaterz } \\
\%\end{array}$ & $\begin{array}{c}\text { Feldspar } \\
\%\end{array}$ & $\begin{array}{c}\text { Dolomite } \\
\%\end{array}$ & $\begin{array}{c}\text { Pyrite } \\
\%\end{array}$ & $\begin{array}{c}\text { Rhodochrosite } \\
\%\end{array}$ & $\begin{array}{c}\text { Illite } \\
\%\end{array}$ \\
\hline \multirow{29}{*}{$\begin{array}{l}\text { Datangpo } \\
\text { Fm. Mn } \\
\text { layer }\end{array}$} & ZK4207-29 & 887.85 & 40 & 16 & 4 & 2 & 1 & 35 \\
\hline & ZK4207-28 & 888.32 & 35 & 15 & 6 & 4 & 2 & 36 \\
\hline & ZK4207-27 & 888.73 & 39 & 12 & 6 & 3 & 4 & 34 \\
\hline & ZK4207-26 & 889.17 & 34 & 12 & 8 & 3 & 12 & 34 \\
\hline & ZK4207-25 & 889.58 & 34 & 10 & 8 & 3 & 11 & 36 \\
\hline & ZK4207-24 & 890.11 & 31 & 5 & 10 & 2 & 16 & 34 \\
\hline & ZK4207-23 & 890.53 & 30 & 4 & 10 & 3 & 16 & 37 \\
\hline & ZK4207-22 & 891.00 & 34 & 3 & 12 & 2 & 18 & 29 \\
\hline & ZK4207-21 & 891.51 & 31 & 6 & 10 & 4 & 12 & 36 \\
\hline & ZK4207-20 & 891.80 & 32 & 6 & 10 & 3 & 11 & 38 \\
\hline & ZK4207-19 & 892.31 & 32 & 7 & 10 & 5 & 16 & 30 \\
\hline & ZK4207-18 & 892.71 & 34 & 4 & 22 & 3 & 12 & 25 \\
\hline & ZK4207-17 & 893.22 & 26 & 2 & 24 & 2 & 22 & 24 \\
\hline & ZK4207-16 & 893.93 & 32 & 4 & 22 & 3 & 16 & 22 \\
\hline & ZK4207-15 & 894.60 & 36 & 4 & 14 & 3 & 18 & 25 \\
\hline & ZK4207-14 & 895.22 & 32 & 4 & 12 & 3 & 20 & 27 \\
\hline & ZK4207-13 & 895.77 & 34 & 5 & 11 & 3 & 20 & 26 \\
\hline & ZK4207-12 & 896.22 & 32 & 6 & 12 & 2 & 22 & 26 \\
\hline & ZK4207-11 & 896.63 & 36 & 7 & 6 & 3 & 10 & 36 \\
\hline & ZK4207-10 & 897.02 & 35 & 8 & 8 & 3 & 10 & 35 \\
\hline & ZK4207-9 & 897.41 & 32 & 6 & 12 & 2 & 12 & 35 \\
\hline & ZK4207-8 & 897.83 & 36 & 5 & 11 & 3 & 12 & 33 \\
\hline & ZK4207-7 & 898.44 & 38 & 5 & 12 & 3 & 14 & 27 \\
\hline & ZK4207-6 & 899.12 & 38 & 8 & 10 & 3 & 9 & 30 \\
\hline & ZK4207-5 & 899.41 & 36 & 8 & 16 & 3 & 18 & 18 \\
\hline & ZK4207-4 & 899.83 & 22 & 3 & 22 & 3 & 35 & 14 \\
\hline & ZK4207-3 & 900.47 & 32 & 8 & 6 & 5 & 4 & 43 \\
\hline & ZK4207-2 & 900.76 & 32 & 2 & 28 & 3 & 13 & 22 \\
\hline & ZK4207-1 & 901.28 & 30 & 6 & 22 & 3 & 2 & 35 \\
\hline
\end{tabular}




\begin{tabular}{|c|c|c|c|c|c|c|c|c|c|c|c|c|c|c|c|c|c|c|c|}
\hline \multicolumn{20}{|c|}{ sodillisto ZK 4207} \\
\hline & Sample & Dopth & $\mathrm{N} ! \mathrm{O}_{1}$ & $\mathrm{BaO}$ & $\infty 0$ & $R_{R}, 0_{2}$ & $\mathrm{k}, \mathrm{O}$ & $\mathrm{M}_{6} \mathrm{O}$ & $\ln , 0, \mathrm{Mas}^{2}$ & NaOO & $\mathrm{P}_{0} \mathrm{O}_{1}$ & $\mathrm{SO}_{3}$ & $\mathrm{TiO}_{3}$ & & & now & & & \\
\hline Tisulizo & 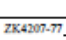 & $\frac{m}{90135}$ & $\frac{5}{1570}$ & $\%$ & $\frac{\%}{028}$ & $\frac{\%}{392}$ & $\frac{\%}{320}$ & $\frac{\%}{0.77}$ & $\frac{\%}{0.10}$ & $\frac{\%}{3.07}$ & $\frac{\%}{a \infty n}$ & $\frac{8}{65.1}$ & $\frac{\%}{0.63}$ & $\frac{8}{500}$ & $\frac{\%}{0.20}$ & $\frac{96}{900}$ & $\frac{\%_{0}}{220}$ & $\frac{m \text { molus }}{1457}$ & malr \\
\hline & 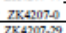 & $\begin{array}{ll}90228 \\
80785\end{array}$ & $\frac{87}{140}$ & $\frac{0.4}{0.98}$ & $\frac{842}{16}$ & $\frac{44}{3.9}$ & $\frac{173}{119}$ & $4+6$ & $\frac{340}{248}$ & $\frac{189}{207}$ & $\frac{a 11}{024}$ & 62 & .039 & $\begin{array}{l}1385 \\
895\end{array}$ & $\frac{402}{175}$ & 10072 & $\frac{313}{277}$ & $\frac{1691}{599}$ & 6 \\
\hline & $2 x<200728$ & 8832 & 1455 & 0.00 & 1.61 & 4.26 & 335 & 1.33 & 4.53 & 189 & 0.25 & 869 & 0.51 & 960 & 239 & 101.27 & 191 & 452 & $\begin{array}{l}808 \\
3316\end{array}$ \\
\hline & 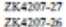 & & $\begin{array}{l}1225 \\
1130 \\
1130\end{array}$ & 里 0.09 & $\begin{array}{l}238 \\
238 \\
285\end{array}$ & $\begin{array}{l}419 \\
410\end{array}$ & 2897 & $\begin{array}{l}171 \\
218 \\
218\end{array}$ & $\begin{array}{l}9.66 \\
13.4 \\
\end{array}$ & $\begin{array}{l}150 \\
130 \\
130\end{array}$ & 然3 & $\begin{array}{c}21 \\
43\end{array}$ & 0.045 & 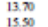 & $\begin{array}{l}207 \\
100 \\
100\end{array}$ & $\begin{array}{l}9027 \\
10048\end{array}$ & $\begin{array}{l}228 \\
293 \\
293\end{array}$ & $\begin{array}{l}419 \\
427\end{array}$ & $\begin{array}{l}559 \\
608\end{array}$ \\
\hline & & 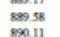 & $\begin{array}{l}1105 \\
1145 \\
871\end{array}$ & .1.19 & 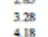 & $\begin{array}{l}387 \\
3.87 \\
3.45\end{array}$ & $\begin{array}{l}200 \\
300 \\
202 \\
20\end{array}$ & 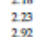 & 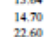 & $\begin{array}{l}1.19 \\
1.98 \\
0.85\end{array}$ & a. & $\begin{array}{l}-7.5 \\
31.5 \\
3.8\end{array}$ & 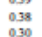 & $\begin{array}{l}1395 \\
120\end{array}$ & $\begin{array}{l}1.85 \\
.0 \%\end{array}$ & $\begin{array}{l}1003 \\
10003 \\
1006\end{array}$ & $\begin{array}{l}200 \\
200 \\
2 \pi\end{array}$ & 年 & $\begin{array}{l}2027 \\
827\end{array}$ \\
\hline & 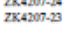 & son.s. & g, & 0.08 & 408 & $\begin{array}{l}374 \\
4.74\end{array}$ & 246 & $2 \pi$ & 20.12 & . & $\begin{array}{l}0.04 \\
0.65\end{array}$ & $\begin{array}{l}32.6 \\
32.4\end{array}$ & 0.32 & 199 & 237 & 100040 & 233 & 300 & $\begin{array}{l}503 \\
503\end{array}$ \\
\hline & 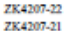 & 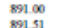 & 6.632 & 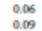 & $\begin{array}{l}603 \\
346 \\
345\end{array}$ & $\begin{array}{l}252 \\
5117 \\
11\end{array}$ & 1,160 & $\begin{array}{l}273 \\
180 \\
180\end{array}$ & 20.35 & $\begin{array}{l}0.63 \\
1.24 \\
0\end{array}$ & 然 025 & $\begin{array}{l}3.66 \\
45\end{array}$ & 0.22 & 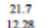 & o. 094 & 10022 & $\begin{array}{l}217 \\
14\end{array}$ & $\begin{array}{l}493 \\
136\end{array}$ & $\begin{array}{l}857 \\
515\end{array}$ \\
\hline & & & 780 & 0.07 & 592 & & 190 & 219 & 1743 & 102 & 0.23 & 390 & 0.38 & 17.35 & & 9988 & & & \\
\hline & & 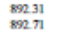 & $\begin{array}{l}771 \\
648 \\
648\end{array}$ & 然. 0.6 & $\begin{array}{l}5.51 \\
723\end{array}$ & $\begin{array}{l}442 \\
361 \\
361\end{array}$ & 1.79 & $\begin{array}{l}230 \\
272 \\
272\end{array}$ & $\begin{array}{l}2008 \\
20136 \\
2316\end{array}$ & o. 098 & 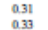 & $\begin{array}{l}341 \\
286 \\
26\end{array}$ & 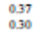 & $\begin{array}{l}194 \\
27\end{array}$ & $\begin{array}{l}265 \\
189 \\
18\end{array}$ & $\begin{array}{l}9959 \\
908\end{array}$ & $\begin{array}{l}1,63 \\
22 n\end{array}$ & 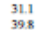 & $\begin{array}{l}612 \\
727 \\
727\end{array}$ \\
\hline & $28<2020-17$ & & 365 & 0.04 & 760 & 3.4 & 090 & 3.4 & & 0.50 & & 201 & 0.21 & 274 & 157 & & 261 & 499 & \\
\hline & 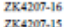 & 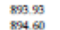 & $\begin{array}{l}\frac{52}{1040} \\
1040\end{array}$ & 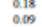 & $\begin{array}{l}\begin{array}{l}673 \\
370\end{array} \\
370\end{array}$ & $\begin{array}{l}3,0 \\
443\end{array}$ & $\begin{array}{l}1.40 \\
251 \\
251\end{array}$ & 3.10 & $\begin{array}{l}28.48 \\
169\end{array}$ & 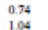 & 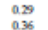 & $\begin{array}{l}275 \\
270 \\
\infty\end{array}$ & $\begin{array}{l}0.28 \\
0.35\end{array}$ & $\begin{array}{l}298 \\
11968\end{array}$ & $\begin{array}{l}149 \\
214\end{array}$ & $\begin{array}{l}10019 \\
10008\end{array}$ & $\begin{array}{l}219 \\
167 \\
\end{array}$ & 47 & $\begin{array}{l}856 \\
856\end{array}$ \\
\hline & 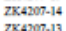 & $\frac{\sin 2 n}{25 x} \pi$ & $\begin{array}{l}976 \\
10.65 \\
105\end{array}$ & 0.12 & $\begin{array}{l}3919 \\
4310\end{array}$ & $\begin{array}{l}3.68 \\
3.13 \\
\end{array}$ & $\begin{array}{l}269 \\
279\end{array}$ & $\begin{array}{l}299 \\
293\end{array}$ & $\begin{array}{l}1932 \\
1714\end{array}$ & $\begin{array}{l}0.78 \\
0.78 \\
0.78\end{array}$ & aid & $\begin{array}{l}36,9 \\
336\end{array}$ & $\begin{array}{l}0.32 \\
0.33 \\
037\end{array}$ & 1939 & 133 & 10097 & $\begin{array}{l}1.74 \\
151\end{array}$ & 288 & 告8 28 \\
\hline & $2 \times 20200-12$ & $\operatorname{sen} 22$ & 998 & 0.07 & 402 & 3.76 & 241 & 27 & 1900 & 0.95 & 0.50 & 3.8 & 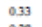 & 193 & 1.49 & 10042 & 1.64 & 19.4 & 372 \\
\hline & 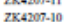 & 8700 & & 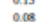 & 280 & & & & & & & & & 1345 & & & & $\begin{array}{l}280 \\
219\end{array}$ & $\begin{array}{l}423 \\
230\end{array}$ \\
\hline & $2 \times 20279$ & 87941 & 204 & o.cos & 431 & 318 & 224 & 263 & 1897 & 104 & 0.55 & 399 & 0.26 & 200 & 1.15 & 10020 & 2066 & 221 & 382 \\
\hline & 07.7 & 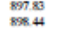 & $\begin{array}{l}956 \\
876 \\
876\end{array}$ & 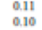 & $\begin{array}{l}5.4 \\
4.4 \\
4\end{array}$ & 3.02 & $\begin{array}{l}2238 \\
193\end{array}$ & $\begin{array}{l}2007 \\
2000\end{array}$ & $\begin{array}{l}14.7 \\
14.1\end{array}$ & $\begin{array}{l}0.93 \\
1.13\end{array}$ & 0.38 & $\begin{array}{l}4.0 \\
45.5\end{array}$ & 02 & $\begin{array}{lll}160.05 \\
1605\end{array}$ & 1,168 & $\begin{array}{l}1 \\
090613 \\
9938\end{array}$ & 198 & 304 & $\begin{array}{l}156 \\
477\end{array}$ \\
\hline & & $\$ \$ 112$ & 1150 & 0.06 & 380 & & & & & & & & & & & & & & 164 \\
\hline & 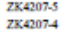 & 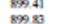 & $\begin{array}{l}9835 \\
3998\end{array}$ & $\begin{array}{l}0.07 \\
0.04\end{array}$ & $67 \pi$ & 3.44 & $\begin{array}{l}247 \\
0.971\end{array}$ & $\begin{array}{l}254 \\
3.16\end{array}$ & 198. & $\begin{array}{l}1089 \\
0.58\end{array}$ & $\begin{array}{l}0.31 \\
0.6\end{array}$ & $\begin{array}{l}33.4 \\
220\end{array}$ & & $\begin{array}{l}193 \\
227\end{array}$ & 169 & 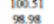 & 34 & 45 & $\begin{array}{l}711 \\
71.1\end{array}$ \\
\hline & & & & & & & & & & & & & & & & & & & 473 \\
\hline & & & & & & & & . & & & & & & & & & & $\begin{array}{l}365 \\
463 \\
419\end{array}$ & $\begin{array}{l}653 \\
573\end{array}$ \\
\hline & & & 18: & & & & & & & & & & & & & & & & \\
\hline & & & & & & & & & & & & & & & & & & & \\
\hline $\mathbf{m}$ & & 80.23 & $\begin{array}{l}1350 \\
1360\end{array}$ & : & $\begin{array}{l}0.4 \\
0.4\end{array}$ & 47 & & $\begin{array}{l}1.02 \\
0.74\end{array}$ & al & & 0.21 & 66.2 & & 688 & & & & & 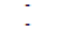 \\
\hline & 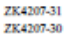 & 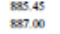 & $\begin{array}{l}11535 \\
17355\end{array}$ & $\begin{array}{l}0.03 \\
0.09\end{array}$ & $\begin{array}{l}0.80 \\
0.38\end{array}$ & 335 & 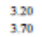 & $\begin{array}{l}\text { ent } \\
\text { o.6.61 }\end{array}$ & $\begin{array}{l}a 19 \\
\text { a.10 }\end{array}$ & $\begin{array}{l}233 \\
284\end{array}$ & $\begin{array}{l}a, a b 1 \\
a x\end{array}$ & 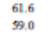 & 0.72 & $\begin{array}{l}892 \\
9.49 \\
9.45\end{array}$ & $\begin{array}{l}0.044 \\
0.27\end{array}$ & $\begin{array}{l}92926 \\
929,4\end{array}$ & $\begin{array}{l}3.99 \\
3.44\end{array}$ & $\begin{array}{l}504 \\
0.24\end{array}$ & - \\
\hline & 77.36 & 388 & 1770 & 0.06 & 0.52 & 660 & 292 & 226 & a.18 & 242 & $a, s$ & 61.9 & 0.67 & $3 \pi$ & 0.29 & $\$ 37$ & 0.2 & 142 & . \\
\hline $\mathrm{Fm}$ & & & & & 0.80 & & & 1.62 & $a$ & & & 6382 & 0.66 & 518 & 0.36 & $\infty+\infty$ & & & \\
\hline & & & & & & & & & & & & & & & & & & & \\
\hline
\end{tabular}




\begin{tabular}{|c|c|c|c|c|c|c|c|c|c|c|c|c|c|c|c|}
\hline \multirow{2}{*}{$\mathrm{Fm}$} & \multirow[b]{2}{*}{ Sample } & \multicolumn{13}{|c|}{ Table 3 . Trace elements analysis results from } & \multirow{2}{*}{$\begin{array}{c}\mathrm{ZI} \\
\mathrm{ppm}\end{array}$} \\
\hline & & $\underset{\mathrm{ppm}}{\mathrm{Ga}}$ & $\mathrm{Ge}$ & $\begin{array}{c}\mathrm{Rb} \\
\mathrm{ppm}\end{array}$ & $\begin{array}{c}\mathrm{Sr} \\
\mathrm{pgm}\end{array}$ & $\mathrm{sc}$ & $\mathrm{Cu}$ & $\mathrm{v}$ & $\mathrm{Cr}$ & $\mathrm{Ni}$ & Co & $\mathrm{U}$ & $\mathrm{Th}$ & $\mathrm{Zn}$ & \\
\hline Tiesi'ao & ZK4207-77 & 24.3 & 0.21 & 133.0 & $\frac{74}{74}$ & $\frac{\mathrm{p}}{12}$ & $\frac{40}{40}$ & 121 & 54 & 71 & $\frac{24}{24}$ & 3.2 & $\frac{13}{13}$ & $\frac{11}{11}$ & 204 \\
\hline \multirow{14}{*}{$\mathrm{Fm}$. Shale } & $\mathrm{ZK} 4207-0$ & 13.2 & 0.18 & 71.5 & 258 & 9 & 29 & 46 & 28 & 14 & 13 & 2.7 & 9 & 32 & 205 \\
\hline & $\mathrm{ZK} 4207-29$ & 19.50 & 0.20 & 118.0 & 117.5 & 11.3 & 35.4 & 62 & 41 & 23.4 & 17.6 & 2.8 & 12 & 35 & 154.0 \\
\hline & $\mathrm{ZK} 4207-28$ & 20.6 & 0.18 & 116.5 & 98.7 & 11.2 & 36.3 & 64 & 41 & 25.4 & 19.7 & 2.7 & 13 & 77 & 158.0 \\
\hline & ZK4207-27 & 17.70 & 0.18 & 95.9 & 113.0 & 10.0 & 30.3 & 64 & 41 & 23.5 & 21.3 & 2.5 & 13 & 76 & 142.5 \\
\hline & $\mathrm{ZK} 4207-26$ & 17.40 & 0.21 & 103.5 & 119.5 & 9.8 & 27.6 & 47 & 30 & 21.3 & 22.7 & 2.4 & 12 & 58 & 131.0 \\
\hline & $\mathrm{ZK} 4207-25$ & 18.35 & 0.22 & 109.5 & 158.5 & 9.8 & 30.1 & 46 & 29 & 23.7 & 27.8 & 2.4 & 12 & 65 & 132.0 \\
\hline & $\mathrm{ZK} 4207-24$ & 13.20 & 0.21 & 79.9 & 160.5 & 7.8 & 20.2 & 41 & 23 & 19.8 & 34.1 & 2.1 & 9 & 54 & 100.0 \\
\hline & $\mathrm{ZK} 4207-23$ & 14.25 & 0.19 & 92.1 & 147.5 & 7.7 & 27.5 & 44 & 24 & 28.7 & 44.6 & 2.1 & 9 & 75 & 104.0 \\
\hline & $\mathrm{ZK} 4207-22$ & 9.04 & 0.17 & 58.2 & 183.5 & 5.4 & 15.5 & 36 & 16 & 19.8 & 27.7 & 1.8 & 5 & 49 & 64.1 \\
\hline & $\mathrm{ZK} 4207-21$ & 18.40 & 0.17 & 87.2 & 133.0 & 8.4 & 45.7 & 65 & 30 & 30.5 & 31.1 & 3.4 & 13 & 64 & 128.5 \\
\hline & ZK $4207-20$ & 11.90 & 0.19 & 68.5 & 185.0 & 6.6 & 33.0 & 58 & 25 & 25.2 & 27.7 & 3.0 & 8 & 49 & 89.5 \\
\hline & ZK $4207-19$ & 11.90 & 0.15 & 68.3 & 203.0 & 6.2 & 34.4 & 60 & 23 & 26.8 & 28.3 & 2.1 & 7 & 54 & 90.1 \\
\hline & $\mathrm{ZK} 4207-18$ & 9.62 & 0.16 & 52.7 & 268.0 & 5.5 & 29.6 & 54 & 19 & 21.0 & 23.5 & 1.6 & 6 & 122 & 73.9 \\
\hline & ZK4207-17 & 6.10 & 0.15 & 30.8 & 257.0 & 3.5 & 23.8 & 42 & 13 & 18.4 & 21.3 & 1.0 & 4 & 30 & 45.5 \\
\hline \multirow{17}{*}{$\begin{array}{l}\text { Datangpo } \\
\text { Fm. Mn } \\
\text { layer }\end{array}$} & $\mathrm{ZK} 4207-16$ & 8.71 & 0.17 & 48.5 & 297.0 & 4.5 & 19.0 & 42 & 16 & 16.4 & 21.0 & 1.5 & 6 & 62 & 61.7 \\
\hline & ZK4207-15 & 14.55 & 0.20 & 96.9 & 182.0 & 8.4 & 28.9 & 42 & 26 & 23.0 & 26.4 & 2.0 & 10 & 56 & 116.5 \\
\hline & $\mathrm{ZK} 4207-14$ & 13.20 & 0.19 & 89.7 & 168.5 & 7.8 & 22.2 & 44 & 25 & 21.4 & 32.6 & 2.1 & 8 & 76 & 101.5 \\
\hline & $\mathrm{ZK} 4207-13$ & 12.70 & 0.23 & 99.4 & 192.0 & 8.7 & 30.8 & 56 & 27 & 34.4 & 46.1 & 2.6 & 9 & 95 & 102.0 \\
\hline & $\mathrm{ZK} 4207-12$ & 11.25 & 0.19 & 87.0 & 175.0 & 7.0 & 26.3 & 48 & 28 & 28.0 & 39.3 & 2.2 & 10 & 56 & 98.7 \\
\hline & $\mathrm{ZK} 4207-11$ & 10.85 & 0.17 & 85.5 & 148.0 & 6.8 & 25.7 & 48 & 48 & 24.6 & 34.8 & 2.3 & 7 & 574 & 84.2 \\
\hline & $\mathrm{ZK} 4207-10$ & 14.55 & 0.20 & 103.5 & 137.5 & 8.5 & 35.7 & 68 & 38 & 38.8 & 39.6 & 3.1 & 11 & 313 & 122.0 \\
\hline & $\mathrm{ZK} 4207-9$ & 9.94 & 0.19 & 80.1 & 164.0 & 7.4 & 25.2 & 51 & 28 & 34.3 & 47.5 & 2.4 & 7 & 72 & 86.8 \\
\hline & $\mathrm{ZK} 4207-8$ & 9.33 & 0.17 & 81.2 & 182.0 & 7.9 & 27.9 & 54 & 31 & 38.0 & 37.8 & 2.3 & 7 & 74 & 91.2 \\
\hline & $\mathrm{ZK} 4207-7$ & 10.85 & 0.18 & 75.5 & 186.0 & 6.2 & 28.5 & 46 & 31 & 29.4 & 30.9 & 2.0 & 7 & 84 & 86.5 \\
\hline & $\mathrm{ZK} 4207-6$ & 14.20 & 0.18 & 73.1 & 131.0 & 12.5 & 20.9 & 52 & 30 & 24.4 & 21.2 & 3.4 & 11 & 74 & 110.5 \\
\hline & $\mathrm{ZK} 4207-5$ & 14.25 & 0.16 & 88.2 & 156.0 & 6.3 & 22.7 & 47 & 22 & 20.6 & 29.4 & 2.6 & 9 & 71 & 102.0 \\
\hline & $\mathrm{ZK} 4207-4$ & 6.38 & 0.14 & 34.5 & 269.0 & 4.0 & 20.5 & 47 & 24 & 18.5 & 21.5 & 1.1 & 4 & 44 & 47.0 \\
\hline & $\mathrm{ZK} 4207-3$ & 18.65 & 0.17 & 101.5 & 107.5 & 10.3 & 65.8 & 86 & 46 & 39.8 & 39.6 & 2.7 & 13 & 109 & 138.5 \\
\hline & $\mathrm{ZK} 4207-2$ & 6.54 & 0.17 & 34.0 & 183.5 & 4.5 & 34.5 & 63 & 23 & 22.7 & 22.9 & 0.9 & 3 & 34 & 42.4 \\
\hline & $\mathrm{ZK} 4207-1$ & 16.35 & 0.18 & 104.5 & 178.0 & 9.4 & 51.4 & 71 & 35 & 36.2 & 22.6 & 3.3 & 12 & 93 & 110.5 \\
\hline & $\mathrm{ZK} 4207-35$ & 25.2 & 0.23 & 156.5 & 67.6 & 13.3 & 44.0 & 63 & 42 & 28.6 & 25.5 & 3.4 & 17 & 78 & 177.5 \\
\hline \multirow{5}{*}{$\begin{array}{l}\text { Datangpo } \\
\text { Fm. Black } \\
\text { shale }\end{array}$} & $\mathrm{ZK} 4207-34$ & 23.7 & 0.21 & 143.5 & 96.8 & 15.7 & 65.3 & 78 & 49 & 41.4 & 19.7 & 2.8 & 13 & 92 & 152.5 \\
\hline & $\mathrm{ZK} 4207-33$ & 22.7 & 0.19 & 130.0 & 80.5 & 14.1 & 53.0 & 70 & 45 & 29.4 & 16.6 & 2.5 & 12 & 89 & 147.0 \\
\hline & $\mathrm{ZK} 4207-32$ & 20.1 & 0.19 & 118.0 & 78.2 & 11.5 & 39.0 & 62 & 58 & 25.6 & 19.6 & 2.2 & 11 & 83 & 122.0 \\
\hline & ZK4207-31 & 22.3 & 0.23 & 137.0 & 133.0 & 12.5 & 35.5 & 67 & 62 & 20.3 & 21.5 & 2.1 & 12 & 52 & 119.5 \\
\hline & $\mathrm{ZK} 4207-30$ & 24.3 & 0.17 & 148.0 & 101 & 14 & 55 & 73 & 60 & 37 & 31 & 3.5 & 20 & 40 & 247 \\
\hline \multicolumn{16}{|c|}{ Datangpo } \\
\hline $\begin{array}{l}\text { Fm.Siltsto } \\
\text { ne }\end{array}$ & $\mathrm{ZK} 4207-36$ & 25.8 & 0.24 & 128.5 & 72 & 14 & 29 & 71 & 42 & 26 & 7 & 2.7 & 12 & 112 & 186 \\
\hline Nantuo & $\mathrm{ZK} 4207-37$ & 23.4 & 0.26 & 125.5 & 96.2 & 13.2 & 11.8 & 68 & 51 & 21.3 & 22.6 & 3.8 & 9.1 & 156 & 198.5 \\
\hline & ZK4207-38 & 17.25 & 0.19 & 148.5 & 72.2 & 9.8 & 3.7 & 46 & 39 & 13.5 & 5.8 & 1.6 & 13.2 & 47 & 109.0 \\
\hline
\end{tabular}




\begin{tabular}{|c|c|c|c|c|c|c|c|c|c|c|c|c|c|c|c|c|c|c|c|c|}
\hline $\mathrm{Fm}$ & Sample & La & $\mathrm{Ce}_{\mathrm{e}}$ & & $\mathrm{Nd}$ & Sm & Eu & $\mathrm{Gd}$ & To & Dy & Hо & Er & Tm & $\mathrm{yb}_{0}$ & & & $\mathrm{Y}$ & cercet & $\mathrm{EuEu}^{*}$ & $\mathrm{~L}_{a_{N} / \mathrm{b}_{3}}$ \\
\hline Tiesizo & $2 \times 4207-7$ & $\frac{p p m}{37.3}$ & $\frac{p p m}{844}$ & ppum & ppm & ppm & ppm & $\frac{p p m}{41}$ & ppm & ppm & ppm & ppm & $\frac{p p m}{0.5}$ & $\frac{\mathrm{pmm}}{\mathrm{pm}}$ & $\frac{p p m}{p e n}$ & 1091 & pppm & & & \\
\hline Fm Shale & & & & 6.7 & & & & & & & & & & & & & & & & $\begin{array}{l}0.80 \\
0.62\end{array}$ \\
\hline & 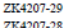 & $\begin{array}{l}41.5 \\
4\end{array}$ & $\begin{array}{l}83.1 \\
83.3\end{array}$ & 9.6 & 41.3 & 8.4 & 1.4 & 7.4 & 1.2 & 6.9 & 1.3 & 3.8 & 0.6 & 3.8 & 0.5 & 210.8 & 40.0 & 0.98 & 0.77 & $\begin{array}{l}0.72 \\
0.70\end{array}$ \\
\hline & & 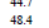 & $\begin{array}{l}85.3 \\
92.8\end{array}$ & 11.6 & $\begin{array}{l}\text { Sits } \\
502\end{array}$ & 115 & $\begin{array}{l}1.6 \\
2.5\end{array}$ & $\begin{array}{c}7.8 \\
1.10 \\
110\end{array}$ & $\begin{array}{l}12 \\
11\end{array}$ & $\begin{array}{l}7.5 \\
100\end{array}$ & $\begin{array}{l}1.5 \\
20\end{array}$ & $\begin{array}{l}4.3 \\
5.2\end{array}$ & 0.0 .8 & $\begin{array}{l}4.0 \\
4.6\end{array}$ & $\begin{array}{l}0.6 \\
0.6\end{array}$ & $\begin{array}{l}215.1 \\
2529\end{array}$ & $\begin{array}{l}533 \\
568\end{array}$ & $\begin{array}{l}0.95 \\
0.92\end{array}$ & $\begin{array}{l}0.06 \\
0.06\end{array}$ & $\begin{array}{l}0.72 \\
0.68\end{array}$ \\
\hline & $\mathrm{ZKK} 4207-26$ & 495 & 1045 & 12.6 & 53.1 & 121 & 2.8 & 120 & 19 & 11.1 & 22 & 5.8 & 0.8 & 4.7 & 0.6 & 273.7 & 6.15 & 0.98 & 1.00 & $\begin{array}{l}0.08 \\
0.68\end{array}$ \\
\hline & $\begin{array}{l}\mathrm{ZKK} \\
\mathrm{ZK} 42072-25\end{array}$ & $\begin{array}{l}53.6 \\
50.0\end{array}$ & $\begin{array}{l}111.60 \\
122.0\end{array}$ & $\begin{array}{l}1.3 .5 \\
13.2\end{array}$ & $\begin{array}{l}56.1 \\
56.0\end{array}$ & $\begin{array}{l}122 \\
13.0\end{array}$ & $\begin{array}{l}3.1 \\
3.4\end{array}$ & $\begin{array}{l}11.9 \\
13.1\end{array}$ & $\begin{array}{l}1,0 \\
2.0\end{array}$ & $\begin{array}{l}111.1 \\
11.9\end{array}$ & $\begin{array}{l}2.2 \\
2.3\end{array}$ & $\begin{array}{l}6.1 \\
6.2\end{array}$ & $\begin{array}{l}0.9 \\
0.9\end{array}$ & $\begin{array}{l}5.1 \\
5.2\end{array}$ & $\begin{array}{l}0.7 \\
0.7\end{array}$ & $\begin{array}{l}20944 \\
2079\end{array}$ & $\begin{array}{l}62.0 \\
65.3\end{array}$ & $\begin{array}{l}1.01 \\
1.10\end{array}$ & $\begin{array}{l}1.11 \\
1.13\end{array}$ & $\begin{array}{l}0.68 \\
0.06\end{array}$ \\
\hline & $2 \times 4207-23$ & 520 & 1119.5 & 12.4 & $\begin{array}{l}52.2 \\
302\end{array}$ & 11.5 & 2.7 & 111.0 & 1.7 & 10.1 & 20 & 5.4 & 0.8 & $\begin{array}{l}4.6 \\
; .8\end{array}$ & 0.7 & 2886.6 & 57.5 & 1.11 & 1.04 & 0.73 \\
\hline & & & 1335 & 126 & 522 & & & 83 & & 83 & 17 & & 0.8 & $\begin{array}{l}28 \\
47\end{array}$ & 0.7 & $\begin{array}{l}21258 \\
2089\end{array}$ & $\begin{array}{l}7.83 \\
473\end{array}$ & 1.74 & 0.74 & $\begin{array}{l}0.64 \\
0.81\end{array}$ \\
\hline & $\mathrm{ZK} \times 207-20$ & 55.7 & 137.5 & 12.8 & 52.0 & 10.2 & 1.8 & 8.5 & 1.4 & 8.6 & 1.8 & 4.9 & 0.8 & 4.5 & 0.6 & 30.1 & 50.0 & 1.21 & 0.84 & 0.80 \\
\hline & $2 \mathrm{ZK}+207-19$ & $\begin{array}{l}4.27 \\
.25\end{array}$ & 1090.0 & 9.7 & 40.4 & 8.2 & 1.7 & 7.2 & 1.2 & 7.2 & 1.4 & 4.1 & 0.6 & 3.6. & 0.5 & & 39.7 & & & 0.77 \\
\hline & 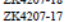 & & & & 310 & & & 60 & & & & & 05 & 28 & 04 & 1804 & 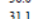 & 1,33 & 10 & $\begin{array}{l}0.72 \\
0.74\end{array}$ \\
\hline & $2 \times 4207-16$ & 31.0 & 78.6 & 7.2 & 31.4 & 7.2 & 1.8 & 6.3 & 0.9 & 6.0 & 1.2 & 3.4 & 0.5 & 3.0 & 0.4 & 1789 & 33.1 & 1.24 & 1.16 & 0.67 \\
\hline & 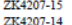 & $\begin{array}{l}432 \\
4369\end{array}$ & $\begin{array}{l}10.4 \\
1055\end{array}$ & 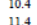 & $\begin{array}{l}453.3 \\
\text { atog }\end{array}$ & 102 & $\begin{array}{l}2.5 \\
2,7\end{array}$ & $\begin{array}{l}1.00 \\
100\end{array}$ & $\begin{array}{l}15 \\
115\end{array}$ & $\begin{array}{l}9.1 \\
0.98\end{array}$ & $\begin{array}{l}18 \\
1.8\end{array}$ & 5 & $\begin{array}{l}0.7 \\
0.8\end{array}$ & 4.3 & $\begin{array}{l}0.6 \\
0.67\end{array}$ & $\begin{array}{l}2363 \\
263\end{array}$ & $\begin{array}{l}50.5 \\
50.5\end{array}$ & 1.02 & 1.07 & 0.65 \\
\hline & $28+207-13$ & 577 & 1370 & 140 & 600 & 140 & 2.6 & 12.1 & 1.8 & 1.1 .2 & 2.1 & 5.7 & 0.9 & 5.2 & 0.7 & $\begin{array}{l}3250 \\
3250\end{array}$ & 6.13 & 1.13 & 0.87 & $\begin{array}{l}0.64 \\
0.72\end{array}$ \\
\hline & $2 \mathrm{ZK} 4207-12$ & 532.2 & 121.5 & 12.8 & 54.8 & 11.9 & 2.5 & 10.9 & 1.7 & 10.1 & 1.9 & 5.1 & 0.8 & 4.8 & 0.7 & 202.7 & 55.8 & 1.10 & 0.95 & 0.72 \\
\hline & $\begin{array}{l}2482077-11 \\
7\end{array}$ & 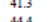 & $\begin{array}{l}922 \\
0.222\end{array}$ & $\begin{array}{l}100 \\
106\end{array}$ & $\begin{array}{l}429 \\
457\end{array}$ & $\begin{array}{l}0.88 \\
102\end{array}$ & 1.8 & $\begin{array}{l}9.1 \\
0.5\end{array}$ & $\begin{array}{l}13 \\
1.4\end{array}$ & 8.9 & 1.8 & 4.9 & 0.7 & $\begin{array}{ll}4.4 \\
4\end{array}$ & 0.6 & 22998 & $\begin{array}{l}49.6 \\
40.6\end{array}$ & $\begin{array}{l}1.07 \\
.107\end{array}$ & 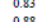 & 0.61 \\
\hline & $\mathrm{ZKK}+207.9$ & 519 & 1310 & 129 & 547.7 & 128 & 2.3 & 11.7 & 1.7 & 10.8 & 20 & 5.6 & 0.8 & 5.0 & 0.7 & 3039 & 56.7 & 1.19 & 0.81 & $\begin{array}{l}0.01 \\
0.67\end{array}$ \\
\hline & $2 \mathrm{ZK} 4207-8$ & 43.4 & 99.2 & 10.7 & 47,7 & 12.3 & 2,4 & 12.5 & 1.8 & 10.6 & 200 & 5.7 & 0.8 & 5.1 & 0.8 & 25500 & 60.2 & 1.08 & 0.84 & 0.55 \\
\hline & 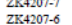 & $\begin{array}{l}3.53 \\
45_{5}\end{array}$ & $\begin{array}{l}8.2 \\
1.25\end{array}$ & $\begin{array}{l}83 \\
100\end{array}$ & $\begin{array}{l}343 \\
\text { silo }\end{array}$ & 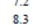 & $\begin{array}{l}1,5 \\
1.6\end{array}$ & $\begin{array}{l}0.8 \\
77_{4}\end{array}$ & $\begin{array}{l}1.0 \\
112\end{array}$ & 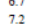 & $\begin{array}{l}13 \\
14\end{array}$ & $\begin{array}{l}3.8 \\
40\end{array}$ & $\begin{array}{l}0.0 \\
0.07\end{array}$ & $\begin{array}{l}3,7 \\
41\end{array}$ & $\begin{array}{l}0.3 \\
0.6\end{array}$ & $\begin{array}{l}1394 \\
2306\end{array}$ & $\begin{array}{l}3.914 \\
4117\end{array}$ & 1.10 & $\begin{array}{l}0.93 \\
0.038\end{array}$ & 0.04 \\
\hline & $\mathrm{ZR} \times 207.5$ & 40.5 & 98.7 & 0.1 & 385 & 7.5 & 1.4 & 6.6 & 11 & 6.6 & 1.4 & 3.9 & 0.6 & 3.8 & 0.6 & 2203 & 379 & 1.21 & 0.86 & $\begin{array}{l}0.72 \\
0.69\end{array}$ \\
\hline & $2 X+2074$ & 30.5 & 78.4 & 7.0 & 30.2 & 7.0 & 1.6 & 6.1 & 0.9 & 5.7 & 1.1 & 3.3 & 0.5 & 2.8 & 0.4 & 1755 & 31.2 & 1.26 & 1.06 & 0.70 \\
\hline & 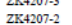 & $\begin{array}{l}5,535 \\
357\end{array}$ & $\begin{array}{l}17173 \\
054\end{array}$ & 89 & 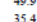 & $\begin{array}{l}9.4 \\
8,3\end{array}$ & 1.8 & 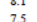 & 13 & . & 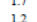 & 年, & 06 & t.1. & 0.7 & 年 & $\begin{array}{l}+5.22 \\
3.46\end{array}$ & 1.09 & 然 & 0.75 \\
\hline & $z B+207-1$ & & & & 45.6 & 8.9 & 1.5 & & 1.2 & & & & 0.7 & 4.6 & 0.7 & 2009 & 43.4 & & 0.76 & 然, \\
\hline & 28420707.35 & 5111 & 110.5 & 12.1 & 4.5 & 8.5 & 1.7 & 7.2 & 1.1. & 72 & 1.5 & 4.6 & & 4.3 & 0.7 & 255.7 & 4.7 & 1.05 & 0.94 & 0.77 \\
\hline & 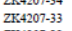 & 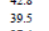 & 77.5 & 9.7 & $\begin{array}{l}38.7 \\
37.7\end{array}$ & 7.8 & 1.5 & 6.7 & 1.0 & $\begin{array}{l}8.8 \\
5.9\end{array}$ & 1.2 & $\begin{array}{l}7.2 \\
3.8\end{array}$ & 0.6 & 3.5 & 0.5 & 1069 & 36.4 & 年 & $\begin{array}{l}0.87 \\
0.90\end{array}$ & $\begin{array}{l}0.69 \\
0.73\end{array}$ \\
\hline shale & 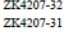 & $\begin{array}{l}3.7 .4 \\
433\end{array}$ & $\begin{array}{l}7.2 \\
91.5 \\
9\end{array}$ & $\begin{array}{l}8.9 \\
10.3\end{array}$ & 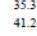 & $\begin{array}{l}6.8 \\
8.3\end{array}$ & $\begin{array}{l}1.3 \\
1.8\end{array}$ & $\begin{array}{l}6.6 \\
8.0\end{array}$ & $\begin{array}{l}1.0 \\
1.3\end{array}$ & 7.1 & $\begin{array}{l}\frac{1.2}{1.5} \\
1.5\end{array}$ & $\begin{array}{l}3.6 \\
4.3 \\
4\end{array}$ & $\begin{array}{l}0.5 \\
0.6\end{array}$ & $\begin{array}{l}3.3 \\
3.4\end{array}$ & $\begin{array}{l}0.5 \\
0.5\end{array}$ & $\begin{array}{l}189.6 \\
223.1\end{array}$ & 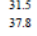 & $\begin{array}{l}\text { l.1.00 } \\
1.02\end{array}$ & $\begin{array}{l}0.84 \\
0.96\end{array}$ & $\begin{array}{l}0.73 \\
0.82 \\
0.82\end{array}$ \\
\hline tangpo & & & & & & & & & & & & & & & & & & & & \\
\hline Silitio & $28 \times 4207.36$ & 39.5 & 790.2 & 89 & 32.6 & 6.5 & 1.4 & 6.5 & 10 & 6.2 & 1.3 & 4.0 & 0.6 & 39 & 0.6 & 1922 & 36.0 & 1.00 & 0.93 & 0.65 \\
\hline & 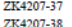 & $\begin{array}{l}48.8 \\
37.8\end{array}$ & $\begin{array}{l}105.5 \\
79.1\end{array}$ & $\begin{array}{l}12.5 \\
{ }_{8.7}\end{array}$ & $\begin{array}{l}49.3 \\
345\end{array}$ & $\begin{array}{l}108 \\
10.8\end{array}$ & 1.7 & $\begin{array}{l}9.7 \\
6.2\end{array}$ & 15 & $\begin{array}{l}8.5 \\
6.1\end{array}$ & $\begin{array}{l}1,7 \\
1,3\end{array}$ & $\begin{array}{l}49 \\
36\end{array}$ & $\begin{array}{l}0.7 \\
0.6\end{array}$ & $\begin{array}{l}49 \\
3.8\end{array}$ & 0.6 & $\begin{array}{l}261.1 \\
1015\end{array}$ & $\begin{array}{l}53.0 \\
351\end{array}$ & $\begin{array}{l}1.00 \\
1.03\end{array}$ & $\begin{array}{l}0.72 \\
0.086\end{array}$ & $\begin{array}{l}0.64 \\
0.64\end{array}$ \\
\hline
\end{tabular}


Table 5. Sr and Nd isotope analysis results from the 1st Member of the Datangpo Formation (dirllsite ZK4207)

\begin{tabular}{|c|c|c|c|c|c|c|c|c|c|c|c|c|c|c|}
\hline $\mathrm{Fm}$ & Samples & Lithology & $\mathrm{T}_{\text {strax: }}(\mathrm{Ma})$ & $\mathrm{Rb}$ (ppm) & $\mathrm{Sr}(\mathrm{ppm})$ & $\mathrm{Sm}(\mathrm{ppm})$ & $\mathrm{Nd}(\mathrm{ppm})$ & ${ }^{87} \mathrm{Rb} /{ }^{56} \mathrm{Sr}$ & ${ }^{147} \mathrm{Sm}^{1 / 44} \mathrm{Nd}$ & Initial ${ }^{87} \mathrm{Sr} /{ }^{86} \mathrm{Sr}$ & $\mathrm{I}^{1+3} \mathrm{Nd}^{1 / 4+} \mathrm{Nd}$ & $\varepsilon_{\mathrm{N} d(t)}$ & $\mathrm{T}_{\mathrm{DM}}(\mathrm{Ga})^{*}$ & $\mathrm{I}_{2 \mathrm{DM}}(\mathrm{Ga})^{*}$ \\
\hline \multirow{30}{*}{ Datangpo } & ZK4207-2 & CMn shale & 660 & 118.0 & 117.5 & 8.4 & 41.3 & 2.9141 & 0.1230 & 0.710038 & 0.511687 & -1.96 & 1.56 & 1.52 \\
\hline & ZK4207-2 & \&n shale & 660 & 116.5 & 98.7 & 8.3 & 41.8 & 3.4259 & 0.1201 & 0.707602 & 0.511664 & -2.41 & 1.57 & 1.55 \\
\hline & ZK4207-2 & iMn shale & 660 & 95.9 & 113.0 & 11.5 & 50.2 & 2.4618 & 0.1385 & 0.710815 & 0.511644 & -2.80 & 1.83 & 1.59 \\
\hline & ZK4207-2 & (Mn ore & 660 & 103.5 & 119.5 & 12.1 & 53.1 & 2.5119 & 0.1378 & 0.708132 & 0.511659 & -2.50 & 1.79 & 1.56 \\
\hline & ZK4207-2: & Mn ore & 660 & 109.5 & 158.5 & 12.2 & 56.1 & 2.0033 & 0.1315 & 0.711594 & 0.511649 & -2.70 & 1.72 & 1.58 \\
\hline & ZK4207-2 & $\angle$ Mn ore & 660 & 79.9 & 160.5 & 13.0 & 56.0 & 1.4431 & 0.1404 & 0.713271 & 0.511642 & -2.84 & 1.87 & 1.59 \\
\hline & ZK4207-2. & Mn ore & 660 & 92.1 & 147.5 & 11.5 & 52.2 & 1.8101 & 0.1332 & 0.710056 & 0.511622 & -3.23 & 1.80 & 1.62 \\
\hline & ZK4207-2 & Mn ore & 660 & 58.2 & 183.5 & 8.5 & 39.2 & 0.9190 & 0.1311 & 0.713859 & 0.511650 & -2.68 & 1.72 & 1.58 \\
\hline & ZK4207-2 & Mn shale & 660 & 87.2 & 133.0 & 9.3 & 52.2 & 1.9011 & 0.1077 & 0.711690 & 0.511670 & -2.29 & 1.46 & 1.54 \\
\hline & ZK4207-2 & ( Mn ore & 660 & 68.5 & 185.0 & 10.2 & 52.0 & 1.0731 & 0.1186 & 0.714413 & 0.511620 & -3.27 & 1.63 & 1.62 \\
\hline & ZK4207-1 & @ Mn ore & 660 & 68.3 & 203.0 & 8.2 & 40.4 & 0.9751 & 0.1227 & 0.715082 & 0.511591 & -3.83 & 1.72 & 1.67 \\
\hline & ZK4207-1 & Mn ore & 660 & 52.7 & 268.0 & 7.7 & 34.4 & 0.5698 & 0.1353 & 0.718077 & 0.511567 & -4.31 & 1.94 & 1.71 \\
\hline & ZK4207-1 & ¡Mn ore & 660 & 30.8 & 257.0 & 6.4 & 31.0 & 0.3472 & 0.1248 & 0.717318 & 0.511576 & -4.13 & 1.77 & 1.69 \\
\hline & ZK4207-1 & Mn ore & 660 & 48.5 & 297.0 & 7.2 & 31.4 & 0.4732 & 0.1386 & 0.719335 & 0.511576 & -4.12 & 1.97 & 1.69 \\
\hline & ZK4207-1 & Mn ore & 660 & 96.9 & 182.0 & 10.2 & 45.3 & 1.5436 & 0.1362 & 0.714136 & 0.511636 & -2.95 & 1.81 & 1.60 \\
\hline & ZK4207-1 & Mn ore & 660 & 89.7 & 168.5 & 11.0 & 49.8 & 1.5433 & 0.1336 & 0.713600 & 0.511624 & -3.18 & 1.80 & 1.62 \\
\hline & ZK4207-1 & Mn ore & 660 & 99.4 & 192.0 & 14.0 & 60.0 & 1.5007 & 0.1411 & 0.712723 & 0.511600 & -3.66 & 1.97 & 1.66 \\
\hline & ZK4207-1 & Mn ore & 660 & 87.0 & 175.0 & 11.9 & 54.8 & 1.4412 & 0.1313 & 0.713955 & 0.511658 & -2.52 & 1.71 & 1.56 \\
\hline & ZK4207-1 & $1 \mathrm{Mn}$ shale & 660 & 85.5 & 146.0 & 9.8 & 42.9 & 1.6980 & 0.1381 & 0.713537 & 0.511603 & -3.59 & 1.91 & 1.65 \\
\hline & ZK4207-1 & ( Mn shale & 660 & 103.5 & 137.5 & 10.2 & 45.7 & 2.1829 & 0.1350 & 0.710619 & 0.511608 & -3.50 & 1.85 & 1.64 \\
\hline & ZK4207-9 & Mn ore & 660 & 80.1 & 164.0 & 12.8 & 54.7 & 1.4157 & 0.1415 & 0.712735 & 0.511629 & -3.09 & 1.91 & 1.61 \\
\hline & ZK4207-8 & Mn ore & 660 & 81.2 & 182.0 & 12.3 & 47.7 & 1.2932 & 0.1559 & 0.713511 & 0.511577 & -4.12 & 2.36 & 1.69 \\
\hline & ZK4207-7 & Mn ore & 660 & 75.5 & 186.0 & 7.2 & 34.3 & 1.1766 & 0.1269 & 0.715147 & 0.511647 & -2.74 & 1.67 & 1.58 \\
\hline & ZK4207-6 & Mn shale & 660 & 73.1 & 131.0 & 8.3 & 41.9 & 1.6175 & 0.1198 & 0.711472 & 0.511707 & -1.57 & 1.50 & 1.49 \\
\hline & ZK4207-5 & Mn ore & 660 & 88.2 & 156.0 & 7.5 & 38.5 & 1.6386 & 0.1178 & 0.709478 & 0.511666 & -2.36 & 1.55 & 1.55 \\
\hline & ZK4207-4 & Mn ore & 660 & 34.5 & 269.0 & 7.0 & 30.2 & 0.3716 & 0.1402 & 0.718267 & 0.511578 & -4.09 & 2.00 & 1.69 \\
\hline & ZK4207-3 & Mn shale & 660 & 101.5 & 107.5 & 9.4 & 49.9 & 2.7387 & 0.1139 & 0.707585 & 0.511649 & -2.69 & 1.54 & 1.58 \\
\hline & ZK4207-2 & Mn ore & 660 & 34.0 & 183.5 & 8.3 & 35.4 & 0.5366 & 0.1418 & 0.712472 & 0.511517 & -5.28 & 2.15 & 1.79 \\
\hline & ZK4207-1 & Mn shale & 660 & 104.5 & 178.0 & 8.9 & 45.6 & 1.7020 & 0.1180 & 0.712171 & 0.511621 & -3.24 & 1.62 & 1.62 \\
\hline & ZK4207-0 & Mn shale & 660 & 71.5 & 256.0 & 5.2 & 25.6 & 0.8089 & 0.1231 & 0.710314 & 0.511579 & -4.07 & 1.74 & 1.69 \\
\hline
\end{tabular}

*: Nd depleted mantle model ages were calculated using the following equation: $\quad T_{D M}=\frac{1}{\lambda_{\text {Sem }}} \ln \left(1+\frac{0.51315^{-143} \mathrm{Nd} /{ }^{14} \mathrm{Nd}}{0.225-{ }^{147} \mathrm{Sm} /{ }^{14} \mathrm{Nd}}\right)$

**: two-stage Nd model ages $\left(T_{2 D M}\right)$ were calculated for a few samples with ${ }^{147} \mathrm{Sm}^{1 / 4} \mathrm{Nd}$ ratios either $>0.13$ or $<0.10$ in order to minimize the bias of $\mathrm{T}_{\mathrm{DM}}$ caused by significant $\mathrm{Sm} / \mathrm{Nd}$ fractionation. The equation for the calculation of two-state $\mathrm{Nd}$ model ages is $\mathrm{T}_{\mathrm{DDM}}=\frac{1}{\lambda_{\mathrm{Sm}}} \ln \left\{1+\frac{0.51315-\left[{ }^{143} \mathrm{Nd} /{ }^{14+} \mathrm{Nd}-\left({ }^{147} \mathrm{Sm} /{ }^{1+4} \mathrm{Nd}-0.12\right)\left(e^{\lambda t}-1\right)\right.}{0.225-0.12}\right\}$ 